\title{
A Novel Divergent Geminivirus Identified in Asymptomatic New World Cactaceae Plants
}

\author{
Rafaela S. Fontenele 1,2, Andrew M. Salywon ${ }^{3}$, Lucas C. Majure ${ }^{3,4}$, Ilaria N. Cobb 1,5, \\ Amulya Bhaskara 1,6 , Jesús A. Avalos-Calleros ${ }^{7}$, Gerardo R. Argüello-Astorga ${ }^{7}$, \\ Kara Schmidlin 1,2, Anthony Khalifeh 1,2, Kendal Smith 1,2, Joshua Schreck 1,2, \\ Michael C. Lund ${ }^{1,2}$, Matias Köhler ${ }^{8}\left(\mathbb{D}\right.$, Martin F. Wojciechowski ${ }^{2} \mathbb{D}$, Wendy C. Hodgson ${ }^{3}$, \\ Raul Puente-Martinez ${ }^{3}$, Koenraad Van Doorslaer ${ }^{9} \mathbb{D}$, Safaa Kumari ${ }^{10}$, Christian Vernière ${ }^{11,12} \mathbb{D}$, \\ Denis Filloux ${ }^{11,12}$, Philippe Roumagnac ${ }^{11,12} \mathbb{D}$, Pierre Lefeuvre ${ }^{13}$, Simone G. Ribeiro ${ }^{14}(\mathbb{D}$, \\ Simona Kraberger ${ }^{1}$, Darren P. Martin ${ }^{15}$ and Arvind Varsani 1,2,16,17,*(D)
}

1 The Biodesign Center for Fundamental and Applied Microbiomics, Arizona State University, Tempe, AZ 85287, USA; rafasfontenele@asu.edu (R.S.F.); ilaria.cobb@gmail.com (I.N.C.); amulyabhaskara@gmail.com (A.B.); kara.schmidlin@asu.edu (K.S.); akhalif5@asu.edu (A.K.); krsmit39@asu.edu (K.S.); jrschrec@asu.edu (J.S.); mclund2@asu.edu (M.C.L.); simona.kraberger@asu.edu (S.K.)

2 School of Life Sciences, Arizona State University, Tempe, AZ 85287, USA; Martin.Wojciechowski@asu.edu

3 Desert Botanical Garden, Phoenix, AZ 85008, USA; asalywon@dbg.org (A.M.S.); lmajure@floridamuseum.ufl.edu (L.C.M.); whodgson@dbg.org (W.C.H.); rpuente@dbg.org (R.P.-M.)

4 Florida Museum of Natural History, University of Florida, Gainesville, FL 32611, USA

5 The University of British Columbia, Vancouver, BC V6T 1Z4, Canada

6 Center for Research in Engineering, Science and Technology, Paradise Valley High School, 3950 E Bell Rd, Phoenix, AZ 85032, USA

7 División de Biología Molecular, Instituto Potosino de Investigación Científica y Tecnológica, A.C., Camino a la Presa de San José 2055, Lomas 4ta Secc, San Luis Potosi 78216, S.L.P., Mexico; jesus.avalos@ipicyt.edu.mx (J.A.A.-C.); grarguel@ipicyt.edu.mx (G.R.A.-A.)

8 Departamento de BotânicaPrograma de Pós-Graduação em Botânica, Universidade Federal do Rio Grande do Sul, Porto Alegre, RS 91501970, Brazil; matias.k@ufrgs.br

9 School of Animal and Comparative Biomedical Sciences, Department of Immunobiology, BIO5 Institute, and UA Cancer Center, University of Arizona, Tucson, AZ 85721, USA; vandoorslaer@email.arizona.edu

10 International Center for Agricultural Research in the Dry Areas (ICARDA), Terbol Station, Beqa'a, Zahle, Lebanon; s.kumari@cgiar.org

11 CIRAD, BGPI, 34398 Montpellier, France; christian.verniere@cirad.fr (C.V.); denis.filloux@cirad.fr (D.F.); philippe.roumagnac@cirad.fr (P.R.)

12 BGPI, INRAE, CIRAD, SupAgro, Univ Montpellier, 34398 Montpellier, France

13 CIRAD, UMR PVBMT, F-97410 St. Pierre, La Réunion, France; pierre.lefeuvre@cirad.fr

14 Embrapa Recursos Genéticos e Biotecnologia, Brasília, CEP 70770-917, Brazil; simone.ribeiro@embrapa.br

15 Computational Biology Division, Department of Integrative Biomedical Sciences, Institute of Infectious Diseases and Molecular Medicine, University of Cape Town, Observatory, Cape Town 7925, South Africa; darrenpatrickmartin@gmail.com

16 Center for Evolution and Medicine, Arizona State University, Tempe, AZ 85287, USA

17 Structural Biology Research Unit, Department of Clinical Laboratory Sciences, University of Cape Town, Cape Town 7925, South Africa

* Correspondence: arvind.varsani@asu.edu; Tel.: +1-480-727-2093

Received: 15 January 2020; Accepted: 31 March 2020; Published: 3 April 2020

Abstract: Cactaceae comprise a diverse and iconic group of flowering plants which are almost exclusively indigenous to the New World. The wide variety of growth forms found amongst the cacti have led to the trafficking of many species throughout the world as ornamentals. Despite the evolution and physiological properties of these plants having been extensively studied, little research has focused on cactus-associated viral communities. While only single-stranded RNA viruses had ever 
been reported in cacti, here we report the discovery of cactus-infecting single-stranded DNA viruses. These viruses all apparently belong to a single divergent species of the family Geminiviridae and have been tentatively named Opuntia virus $1(\mathrm{OpV} 1)$. A total of 79 apparently complete OpV1 genomes were recovered from 31 different cactus plants (belonging to 20 different cactus species from both the Cactoideae and Opuntioideae clades) and from nine cactus-feeding cochineal insects (Dactylopius sp.) sampled in the USA and Mexico. These $79 \mathrm{OpV} 1$ genomes all share $>78.4 \%$ nucleotide identity with one another and $<64.9 \%$ identity with previously characterized geminiviruses. Collectively, the OpV1 genomes display evidence of frequent recombination, with some genomes displaying up to five recombinant regions. In one case, recombinant regions span $\sim 40 \%$ of the genome. We demonstrate that an infectious clone of an OpV1 genome can replicate in Nicotiana benthamiana and Opuntia microdasys. In addition to expanding the inventory of viruses that are known to infect cacti, the OpV1 group is so distantly related to other known geminiviruses that it likely represents a new geminivirus genus. It remains to be determined whether, like its cactus hosts, its geographical distribution spans the globe.

Keywords: geminivirus; Cactoideae; Opuntioideae; ssDNA virus; cochineal insects

\section{Introduction}

With the exception of a single species, Rhipsalis baccifera (Sols.) Stearn, which is also found in some tropical areas of the Old World, cacti are endemic to the Americas [1]. Cacti have undergone adaptive radiations across a wide variety of edaphically dry environments [1,2], which, together with high degrees of phenotypic diversification within the family, have yielded a broad range of morphological forms [3,4]. Phylogenetic relationships in the family are relatively well-known, and four principle clades have been recovered in analyses (Leuenbergeria, Pereskia, Cactoideae + Maihuenia, and Opuntioideae) [2,5,6]. Cacti are culturally, economically and ecologically important [7]. Since Europeans first arrived in the Americas, cacti have been transported throughout the world [1]: to be grown primarily as ornamentals, but also as a crop for their fruit and stems (known as nopales) and the farming of cochineal insects (Dactylopius spp.), the latter of which are members of the order Hemiptera, used for the production of the carminic acid dye [8].

In 1885, the first evidence of spindle-like structures associated with a virus infection was described from cacti in the genus Epiphyllum [9]. Since then, a handful of viruses have been identified in other members of the Cactaceae, all of which belong to the single-stranded RNA virus families Alphaflexiviridae, Betaflexiviridae, Puribunyaviridae, Tombusviridae and Virgaviridae [10-18]. To our knowledge, no plant-infecting DNA viruses (i.e., viruses belonging to the families Geminiviridae, Nanoviridae, and Caulimoviridae) have ever been found to infect cacti.

High-throughput sequencing (HTS) technologies have led to a dramatic increase in the discovery of novel viruses across ecosystems, and have broadly expanded our knowledge of plant-infecting virus diversity $[19,20]$. The impacts of these technologies on plant virus discovery are evident within the family Geminiviridae, a family of plant viruses for which HTS-based virus discovery projects are uncovering a growing number of divergent lineages. In addition to the nine recognized geminivirus genera-Becurtovirus, Begomovirus, Capulavirus, Curtovirus, Eragrovirus, Grablovirus, Mastrevirus, Topocuvirus and Turncurtovirus; [21,22]—four of which were established based on viruses discovered in large-scale HTS-based virus discovery projects, it is likely that multiple new genera will need to be formed to accommodate 12 other, currently unassigned, divergent geminivirus lineages [23-32].

Although many of the known geminiviruses cause severe economic losses in a variety of crops (i.e., tomato, maize, cotton, cassava and bean plants) [33,34], many of the newly discovered geminiviruses seem to produce either no symptoms or only very mild symptoms, in the host species from which they were isolated $[25,31,35-37]$. 
Besides prompting the founding of new geminivirus genera, newly discovered divergent geminivirus lineages are illuminating the deep evolutionary history of this family. The circular single-stranded DNA genomes of the known geminiviruses are encapsidated in twinned icosahedral particles [38] and encode up to seven genes that are bi-directionally transcribed. The only two genes that are detectably conserved across all of these divergent lineages are a replication associated protein gene (rep) and a capsid protein gene $(c p)$. In addition to these two genes, three others, a replication enhancer protein gene (ren), a C4 gene (which encodes a symptom determinant and/or a silencing suppressor), and a transactivation protein gene (trap), are possibly conserved across the genera Begomovirus, Curtovirus, Eragrovirus, Topocuvirus and Turncurtovirus, although in some cases these genes are only putative homologs [21,39-41]. Although movement protein genes ( $m p)$ appear to occur in all known geminivirus genomes [40,41], there is commonly no detectable homology between the movement proteins (MPs) of viruses in the different geminivirus genera.

Geminiviruses are transmitted by a range of insect vectors in the order Hemiptera. In most cases, only one or a few very closely related vector species in a single genus transmit these viruses in each of the different geminivirus genera. Becurtoviruses, curtoviruses, and turncurtoviruses are known to be transmitted by leafhoppers in the genus Circulifer, begomoviruses by whiteflies in the genus Bemisia, topocuviruses by treehoppers in the genus Micrutalis, grabloviruses by treehoppers in the genus Spissistilus, and capulaviruses by aphids in the genus Aphis [21,33,42-44]. In the case of mastreviruses, however, different virus species are transmitted by insects belonging to different leafhopper species in a number of insect genera including Cicadulina, Orosius, Psammotettix, and Nesoclutha [45].

Although geminivirus research in the past has primarily focused on viruses that are major pathogens of cultivated plants, much recent attention has been given to geminiviruses that circulate within natural ecosystems, especially those at agro-ecological interfaces [46-49]. The spill-over of viruses between agricultural and natural ecosystems can significantly impact both the preservation of natural ecosystems [50,51] and the emergence of new crop pathogens from these ecosystems [52-54].

Here, we describe the characterization of a divergent geminivirus lineage found to infect different cactus species and multiple genera (Opuntia spp., Cylindropuntia spp. and Lophocereus schottii) in the USA and Mexico. The viruses within this lineage have tentatively been grouped with a species named Opuntia virus 1 (OpV1). Infectivity assays involving Nicotiana benthamiana and three Opuntia spp. confirmed that OpV1 was able to asymptomatically infect $N$. benthamiana and O. microdasys.

\section{Materials and Methods}

\subsection{Sample Collection and Processing}

A total of 527 Cactaceae plant samples (Supplementary Data 1) from the Cactoideae and Opuntioideae clades were collected in Argentina $(n=14)$, Bolivia $(n=8)$, Brazil $(n=8)$, Cuba $(n=1)$, Curaçao $(n=1)$, Dominican Republic $(n=2)$, France $(n=20)$, Haiti $(n=2)$, Lebanon $(n=1)$, Morocco $(n=1)$, Mexico $(n=31)$, Paraguay $(n=3)$, Reunion (19), Spain $(n=6)$, Tunisia $(n=10)$, Uruguay $(n=5)$, the United States $(n=394)$ and Venezuela $(n=1)$. Of the cactus samples from the USA, 134 were collected from the cactus collection at the Desert Botanical Garden in Phoenix, Arizona (USA). In addition, 25 non-cactus samples (from the Alliaceae, Amaranthaceae, Apiaceae, Asteraceae, Cucurbitaceae, Lamiaceae, Laureaceae, Malvaceae, Oleaceae and Solanaceae flowering plant families) were also collected from the Desert Botanical Garden in Phoenix, Arizona. Samples were collected using a $3 \mathrm{~mm}$ biopsy punch (Robbins Instruments, Chatham, NJ, USA) or scalpel blades. Although none of the sampled cacti were observed to have obvious infection symptoms, 61 plants were infested with cochineal insects (Dactylopius sp.). Insects from these 61 plants were also collected (see Supplementary Data 1 for details of all the samples analyzed). All samples were stored at $-20^{\circ} \mathrm{C}$ or dried on silica until processing.

Total DNA was extracted from cactus tissue samples using either the GeneJET Plant Genomic DNA Purification Kit (Thermo Fisher Scientific, Waltham, MA, USA) or DNeasy Plant Mini Kit (Qiagen, 
Hilden, Germany) according to the manufacturer's instructions. The cochineal insects (cohorts of 5-10 from a colony) were ground in $200 \mu \mathrm{L}$ of SM Buffer $(0.1 \mathrm{M} \mathrm{NaCl}, 50 \mathrm{mM}$ Tris/HCl-pH 7.4, 10 mM MgSO 4 ) and subsequently centrifuged for $5 \mathrm{~min}$ at 10,000 rpm to pellet cellular material. The supernatant was then used to isolate DNA using the High Pure Viral Nucleic Acid Kit (Roche Diagnostics, Indianapolis, IN, USA). Both plant total DNA and cochineal insect purified viral DNA from each sample were used in a rolling circle amplification (RCA) reaction with the TempliPhi ${ }^{\mathrm{TM}}$ kit (GE Healthcare, Chicago, IL, USA), as described by Shepherd et al. [55].

\subsection{High Throughput Sequencing and Genome Assembly}

Aliquots of the RCA product of each sample were pooled (8 to 10 samples per pool) based on sampling location, and sequenced on an Illumina HiSeq 4000 platform (paired-end $2 \times 100 \mathrm{bp}$ ) at Macrogen Inc. (Seoul, Korea). Raw reads were de novo assembled using SPAdes v. 3.12.0 [56] and the resulting contigs were analyzed using BLASTx [57] against a GenBank viral RefSeq protein database [58]. For contigs with a detectable homology (E-value of $<10^{-5}$ ) to known geminiviruses, abutting primers were designed (OpV1_F 5'-GGG CCC CAA TAA GTT CTT TCC AAT GTT TTA GCT TT-3' and OpV1_R 5'-AAA GAG ACT GGC AAA GCA ACT GTA AAT ACG GCA AG-3') to recover potentially full-length virus genomes from plant and insect samples. The primers were used to amplify the geminivirus genomes using KAPA HiFi HotStart DNA polymerase (KAPA Biosystems, USA), following the manufacturer's thermal cycling condition recommendations. Amplicons were resolved in $0.7 \%$ agarose gel and those with a size of between 2.5 and $3.5 \mathrm{~kb}$ (the expected size-range of geminivirus genomes or genome components) were excised, gel-purified and cloned in the pJET1.2 cloning vector (Thermo Fisher Scientific, Waltham, MA, USA). Cloned amplicons were Sanger sequenced by primer walking at Macrogen Inc. (Seoul, South Korea). Genome assemblies and annotations were performed using Geneious 11.1.5 [59].

\subsection{Infectivity Assays}

One Opuntia-derived geminivirus isolate, OpV1 DBG14_1 (GenBank accession \# MN100000) recovered from O. echios var. echios sampled from the Desert Botanical Garden (Phoenix, AZ, USA) was chosen for the construction of an infectious OpV1 clone. OpV1 F/R primers were phosphorylated using T4 kinase (New England Biolabs, Ipswich, MA, USA) and subsequently used to amplify the genome from OpV1 DBG14_1. The amplified genome was self-ligated using T4 DNA ligase (Thermo Fisher Scientific, Waltham, MA, USA) to generate a circular genome, which was subsequently amplified by RCA with the TempliPhi ${ }^{\mathrm{TM}}$ kit (GE Healthcare, Chicago, IL, USA). The RCA product was then digested with either HindIII to generate a linearized full genome copy (FGC; 2945 nt in length), or with both HindIII and BamHI to generate a near full-length genome copy (nFGC; $2750 \mathrm{nt}$ in length). The FGC and nFGC were individually cloned into the HindIII and/or BamHI restriction enzyme sites of the vector pBlueScript-KS, and Sanger sequenced by primer walking at Macrogen Inc. (Seoul, South Korea). The FGC and nFGC were then cloned in the HindIII/BamHI digested pGTV-kan [60] binary vector and used to transform Escherichia coli XL1 Blue. To confirm two copies had ligated in tandem, clones were tested by digesting them with BamHI. A clone containing tandemly cloned FGC and nFGC was then used to transform Rhizobium radiobacter (synonymous species name for Agrobacterium tumefaciens) GV3101. A glycerol stock of this was prepared and stored at $-80{ }^{\circ} \mathrm{C}$.

Infection assays were performed on N. benthamiana, O. ficus-indica, O. microdasys, O. engelmannii, and O. santa-rita. Rhizobium-mediated OpV1 infections of $N$. benthamiana were performed in three replicates, with 18 inoculated plants in two replicates and seven in the third, including two negative controls (non-inoculated plants) in each replicate. Five opuntia plants for each species were Rhizobium-inoculated, and one plant was used as a negative control. For the Rhizobium-inoculations, $R$. radiobacter was grown for $20 \mathrm{~h}$ in Luria broth with kanamycin $(50 \mu \mathrm{g} / \mathrm{mL})$ and rifampicin $(50 \mu \mathrm{g} / \mathrm{mL})$. The culture was then centrifuged for $10 \mathrm{~min}$ at $4600 \mathrm{rpm}$ to pellet the cells before resuspension in MES buffer (10 mM MES hydrate and $10 \mathrm{mM} \mathrm{MgSO}_{4}$ hepta-hydrate) with acetosyringone $150 \mu \mathrm{M}$ to an OD of 1.0. 
The seven inoculated Nicotiana benthamiana plants from the third infection assay were used for Southern blot analysis. We also included two negative control plants (non-inoculated). Total DNA was extracted from the N. benthamiana plants as described in Section 2.1 and $5 \mu \mathrm{g}$ total DNA from each plant and a positive control ( $5 \mathrm{ng}$ of OpV1 PCR amplicon of the genome) were resolved on a 1\% agarose gel. The resolved nucleic acid was transferred to a positively charged nylon membrane Hybond-N+ (GE Healthcare, Chicago, IL, USA) and UV-crosslinked. The membrane was hybridized with a digoxygenin-labelled specific probe for the OpV1 full genome. The probe synthesis, hybridization and detection were obtained using the DIG High Prime DNA Labeling and Detection Starter Kit I (Roche, Indianapolis, IN, USA) according to the manufacturer's instructions.

\subsection{Phylogenetic and Pairwise Identity Analyses}

Genome-wide pairwise nucleotide sequence identities between the 79 OpV1 genomes were determined using SDT v1.2 [61]. A genotype demarcation threshold of 95\% was selected based on the distribution of pairwise identities and this revealed the existence of 15 genetically distinct OpV1 "genotype groups".

Representative full-length nucleotide sequences from each of these 15 genotype groups, together with the genomes of geminiviruses belonging to the nine classified genera (30 sequences) and those that remained unassigned to a genus (12 sequences), were aligned by MAFFT v.7 [62]. This alignment was used to infer a Neighbor-Joining phylogenetic tree using a Jukes-Cantor substitution model with 1000 bootstrap replicates being used to test branch supports. Branches with $<60 \%$ bootstrap support were collapsed using TreeGraph2 [63], and the phylogenetic tree was midpoint-rooted.

The 79 OpV1 genomes were aligned with MAFFT v.7 [62] and the resulting alignment was used to infer a Neighbor-Joining phylogenetic tree using the Jukes-Cantor substitution model with 1000 bootstrap replicates being used to test branch supports. Branches with $<60 \%$ bootstrap support were collapsed using TreeGraph2 [63]. The OpV1 genome sequences, with recombination regions removed, were used to infer a Maximum-Likelihood (ML) phylogenetic tree using PHYML 3.0 [64] with the GTR $+\Gamma+$ I substitution model selected as best fitting by jModelTest [65].

Datasets were also constructed that contained either the inferred Rep or inferred CP amino acid sequences of one, representative of each of the 15 OpV1genotype groups, along with representative sequences of viruses in the nine established geminivirus genera (30 viruses) and sequences from geminiviruses that remain unassigned to any genus (12 viruses). These Rep and CP amino acid datasets were aligned by MAFFT v.7 [62]. The alignments were used to infer ML phylogenetic trees using PHYML 3.0 [64] with the amino acid substitution models $\mathrm{rtRev}+\mathrm{G}+\mathrm{F}+\mathrm{I}$ used for the $\mathrm{CP}$ dataset and $\mathrm{rtRev}+\Gamma+\mathrm{F}+\mathrm{I}$ used for the Rep dataset (these models were determined as best fitting by ProtTest; [66]), using the approximate likelihood ratio test (aLRT) of branch support. Branches with $<0.8$ aLRT support were collapsed with TreeGraph2 [63] and both ML trees were rooted with sequences of viruses from the family Genomoviridae.

\subsection{Capsid Protein Cluster Analysis}

The CP amino acid sequences of all geminiviruses available in GenBank were extracted and clustered using CD-HIT [67] with a $90 \%$ identity threshold. A representative from each cluster was chosen and together with the $\mathrm{CP}$ amino acid sequences from representatives of the $15 \mathrm{OpV} 1$ genotypes these were used to generate a sequence similarity network using the Enzyme Function Initiative-Enzyme Similarity Tool (EFI-EST) [68]. The network was created using a similarity score of 60 and E-value threshold of $1 \times 10^{-5}$. The network was visualized in Cytoscape v3.7.1 [69] with the organic layout.

\subsection{Recombination Analysis}

The OpV1 genomes $(n=79)$ were aligned by MAFFT v.7 [62] and recombination analysis was performed by RDP4 v.4.97 [70] with default settings using the detection methods RDP [71], 
GENECONV [72], BOOTSCAN [73], MAXCHI [74], CHIMERA [75], SISCAN [76] and 3SEQ [77]. Recombination events that were detected by three or more methods with $p$-values $<0.05$ were accepted as credible.

\subsection{Virus Purification and Transmission Electron Microscopy}

A total of $40 \mathrm{~g}$ of infected $\mathrm{N}$. benthamiana leaves, 21 days post Rhizobium-mediated OpV1 infection, was homogenized in $40 \mathrm{~mL}$ of extraction buffer $(1 \times \mathrm{PBS}$ pH 5.2, $10 \mathrm{mg} / \mathrm{mL}$ sodium ascorbate, $2 \mathrm{mM}$ PMSF, 1 mM EDTA). The homogenate was filtered through two layers of cheese cloth and two layers of miracloth, and thereafter centrifuged for $30 \mathrm{~min}$ at $14,800 \times \mathrm{g}$. The clarified supernatant was kept at $4{ }^{\circ} \mathrm{C}$ overnight and then centrifuged twice for $30 \mathrm{~min}$ at $14,800 \times \mathrm{g}$ and the $\mathrm{pH}$ was adjusted to 7.0. The supernatant was then centrifuged for $4 \mathrm{~h}$ at 32,000 rpm using a Beckman 32 Ti rotor, (Beckman Coulter, Pasadena, CA, USA) onto a 10\% sucrose cushion and the pellet resuspended in $1 \mathrm{~mL}$ of $1 \times$ PBS. A total of $10 \mu \mathrm{L}$ of a 1:10 dilution of the resuspended pellet was absorbed onto a carbon-coated copper grids for $10 \mathrm{~min}$, washed, and negatively stained with $2 \%$ uranyl acetate. The grids were viewed using a Phillips CE 12 transmission electron microscope (Phillips, The Netherlands).

\section{Results and Discussion}

\subsection{A Novel Cactus-Infecting Geminivirus}

In an attempt to determine whether cacti are natural hosts of geminiviruses, we screened a total of 527 cactus samples from 18 countries for the presence of geminiviruses using an HTS approach. Most of the analyzed samples were collected in the USA $(n=394)$ from botanical gardens, herbaria and directly from native habitats. Based on geminivirus-like contigs recovered from these samples by HTS, a pair of abutting primers (OpV1 F/R) were designed to recover the full-length geminivirus-like genomes (or at least components of genomes). Amplicons of approximately $3 \mathrm{~kb}$ in length were produced using these primers from 31 cactus samples and nine cochineal insect samples.

Of the 31 samples found to contain geminivirus-like sequences, two cactus samples were from Mexico, 29 cactus samples were from the USA (Arizona, $n=28$; Texas, $n=1$ ), and all nine of the insect samples were from the USA. Of the areas in the USA where samples were collected, most $(n=20)$ were from the Desert Botanical Garden. Consequently, 25 additional non-cactus samples were collected from the Desert Botanical Garden to potentially identify alternate hosts. However, none of the non-cactus plant samples were found to contain OpV1-like sequences resembling those found in the cactus samples.

We amplified, cloned, and sequenced geminivirus genome-length DNA fragments (2940 to $2962 \mathrm{nt}$ ) from the 31 cactus, and nine insect samples that appeared to contain geminivirus-like DNA. These geminivirus-like genomes were tentatively named Opuntia virus 1 (OpV1), since most of them were retrieved from Opuntia spp. (Table 1). While some of the cochineal insects from which OpV1 genomes were recovered were collected from plants that also contained OpV1 genomes $(n=4)($ Table 1$)$, in other cases, insects containing OpV1 were collected from plants that did not detectably contain such genomes $(n=5)$ (Table 1$)$. 
Table 1. Summary of the isolates, accession number, genotype, host species, collection dates and country from which the 79 genomes of the Opuntia virus 1 has been recovered. Details of the cochineal insects sampled and identification of sub/super-genomic molecules from specific plants are listed.

\begin{tabular}{|c|c|c|c|c|c|c|c|c|}
\hline Virus & Isolate & $\begin{array}{l}\text { Accession } \\
\text { Number }\end{array}$ & Genotype & Host species & Sampling Year & $\begin{array}{l}\text { Region of } \\
\text { Collection }\end{array}$ & $\begin{array}{c}\text { Associated } \\
\text { Insect Samples }\end{array}$ & Sub/Super-Genomic \\
\hline OpV1 & 2013_1 & MN099960 & 4 & \multirow[t]{3}{*}{$\begin{array}{c}\text { Lophocereus } \\
\text { schottii }\end{array}$} & 2015 & Arizona, USA & & \\
\hline OpV1 & 2013_2 & MN099981 & 4 & & 2015 & Arizona, USA & & \\
\hline OpV1 & 2013_3 & MN099982 & 4 & & 2015 & Arizona, USA & & \\
\hline OpV1 & 2014_1 & MN099983 & 4 & \multirow[t]{5}{*}{$\begin{array}{c}\text { Opuntia } \\
\text { stenopetala }\end{array}$} & 2015 & Arizona, USA & & \\
\hline OpV1 & 2014_2 & MN099984 & 4 & & 2015 & Arizona, USA & & \\
\hline OpV1 & 2014_3 & MN099985 & 4 & & 2015 & Arizona, USA & & \\
\hline OpV1 & $2014 \_4$ & MN099986 & 4 & & 2015 & Arizona, USA & & \\
\hline OpV1 & $2014 \_5$ & MN099987 & 4 & & 2015 & Arizona, USA & & \\
\hline OpV1 & ASU_PP2 & MN099961 & 5 & $\begin{array}{l}\text { Cylindropuntia } \\
\text { fulgida }\end{array}$ & 2018 & Arizona, USA & & \\
\hline OpV1 & ASUH_12 & MN099962 & 4 & Opuntia tapona & 2002 & $\begin{array}{c}\text { Baja California, } \\
\text { Mexico }\end{array}$ & & \\
\hline OpV1 & ASUH_16 & MN099963 & 4 & $\begin{array}{c}\text { Opuntia } \\
\text { engelmannii }\end{array}$ & 2010 & Arizona, USA & & \\
\hline OpV1 & ASUH_20 & MN099964 & 4 & $\begin{array}{c}\text { Opuntia } \\
\text { santa-rita }\end{array}$ & 2002 & Sonora, Mexico & & \\
\hline OpV1 & Cacti_2_1 & MN099988 & 6 & \multirow[t]{2}{*}{$\begin{array}{c}\text { Opuntia } \\
\text { santa-rita }\end{array}$} & 2017 & Arizona, USA & SI_7 & \\
\hline OpV1 & Cacti_2_2 & MN099989 & 6 & & 2017 & Arizona, USA & & \\
\hline OpV1 & DBG10_5 & MN099990 & 11 & \multirow[t]{6}{*}{ Opuntia cespitosa } & 2017 & Arizona, USA & & OpV1 sg-1 \\
\hline OpV1 & DBG10_9 & MN099991 & 12 & & 2017 & Arizona, USA & & OpV1 sg-3 \\
\hline OpV1 & DBG10_149 & MN099992 & 11 & & 2017 & Arizona, USA & & \\
\hline OpV1 & DBG10_1972 & MN099993 & 11 & & 2017 & Arizona, USA & & \\
\hline OpV1 & DBG10_2558 & MN099994 & 12 & & 2017 & Arizona, USA & & \\
\hline OpV1 & DBG10_2562 & MN099995 & 11 & & 2017 & Arizona, USA & & \\
\hline OpV1 & DBG13_5 & MN099996 & 11 & \multirow[t]{3}{*}{ Opuntia basilaris } & 2017 & Arizona, USA & & OpV1 sg-2 \\
\hline OpV1 & DBG13_9 & MN099997 & 11 & & 2017 & Arizona, USA & & OpV1 sg-4 \\
\hline OpV1 & DBG13_1987 & MN099998 & 1 & & 2017 & Arizona, USA & & \\
\hline
\end{tabular}


Table 1. Cont.

\begin{tabular}{|c|c|c|c|c|c|c|c|c|}
\hline Virus & Isolate & $\begin{array}{c}\text { Accession } \\
\text { Number }\end{array}$ & Genotype & Host species & Sampling Year & $\begin{array}{l}\text { Region of } \\
\text { Collection }\end{array}$ & $\begin{array}{c}\text { Associated } \\
\text { Insect Samples }\end{array}$ & Sub/Super-Genomic \\
\hline OpV1 & DBG_14_1 & MN100000 & 4 & \multirow[t]{7}{*}{$\begin{array}{l}\text { Opuntia echios } \\
\text { var. echios }\end{array}$} & 2017 & Arizona, USA & \multirow[t]{7}{*}{ SI_1 } & \\
\hline OpV1 & DBG_14_2 & MN100001 & 4 & & 2017 & Arizona, USA & & \\
\hline OpV1 & DBG_14_3 & MN100002 & 7 & & 2017 & Arizona, USA & & \\
\hline OpV1 & DBG_14_4 & MN100003 & 4 & & 2017 & Arizona, USA & & \\
\hline OpV1 & DBG_46 & MN100013 & 4 & & 2018 & Arizona, USA & & \\
\hline OpV1 & DBG_47 & MN100014 & 4 & & 2018 & Arizona, USA & & \\
\hline OpV1 & DBG_48 & MN100015 & 4 & & 2018 & Arizona, USA & & \\
\hline OpV1 & DBG_26 & MN100004 & 11 & Opuntia rufida & 2018 & Arizona, USA & & OpV1 sg-6 \\
\hline OpV1 & DBG_31_1 & MN100005 & 1 & \multirow[t]{2}{*}{$\begin{array}{c}\text { Opuntia } \\
\text { mackensenii }\end{array}$} & 2018 & Arizona, USA & & \\
\hline OpV1 & DBG_31_2 & MN100006 & 1 & & 2018 & Arizona, USA & & \\
\hline OpV1 & DBG34 & MN099999 & 2 & \multirow[t]{2}{*}{ Opuntia robusta } & 2018 & Arizona, USA & \multirow[t]{2}{*}{ SI_33 } & \multirow[t]{2}{*}{ OpV1 sg-8 } \\
\hline OpV1 & DBG_34 & MN100007 & 7 & & 2018 & Arizona, USA & & \\
\hline OpV1 & DBG_36 & MN100008 & 2 & $\begin{array}{c}\text { Opuntia } \\
\text { englemannii x.O. } \\
\text { rufida }\end{array}$ & 2018 & Arizona, USA & SI_35 & \\
\hline OpV1 & DBG_38 & MN100009 & 11 & $\begin{array}{c}\text { Opuntia } \\
\text { martiniana }\end{array}$ & 2018 & Arizona, USA & & \\
\hline OpV1 & DBG_41 & MN100010 & 12 & Opuntia rooneyi & 2018 & Arizona, USA & & OpV1 sg-5 \\
\hline OpV1 & DBG_42_1 & MN100011 & 4 & \multirow[t]{3}{*}{$\begin{array}{c}\text { Opuntia } \\
\text { englemannii }\end{array}$} & 2018 & Arizona, USA & & \multirow[t]{3}{*}{ OpV1 sg-12 } \\
\hline OpV1 & DBG_42_2 & MN100012 & 11 & & 2018 & Arizona, USA & & \\
\hline OpV1 & DBG_42_3 & MN099971 & 10 & & 2018 & Arizona, USA & & \\
\hline OpV1 & DBG_56 & MN099972 & 4 & \multirow[t]{4}{*}{ Opuntia basilaris } & 2018 & Arizona, USA & & \\
\hline OpV1 & DBG_57 & MN099973 & 7 & & 2018 & Arizona, USA & & \\
\hline OpV1 & DBG_577_2 & MN099974 & 7 & & 2018 & Arizona, USA & & \\
\hline OpV1 & DBG_58 & MN099975 & 4 & & 2018 & Arizona, USA & & \\
\hline OpV1 & DBG_72 & MN099976 & 3 & Opuntia rufida & 2018 & Arizona, USA & & \\
\hline
\end{tabular}


Table 1. Cont

\begin{tabular}{|c|c|c|c|c|c|c|c|c|}
\hline Virus & Isolate & $\begin{array}{c}\text { Accession } \\
\text { Number }\end{array}$ & Genotype & Host species & Sampling Year & $\begin{array}{l}\text { Region of } \\
\text { Collection }\end{array}$ & $\begin{array}{c}\text { Associated } \\
\text { Insect Samples }\end{array}$ & Sub/Super-Genomic \\
\hline OpV1 & DBG74 & MN099965 & 4 & Opuntia robusta & 2018 & Arizona, USA & & \\
\hline OpV1 & DBG75 & MN099966 & 4 & Opuntia basilaris & 2018 & Arizona, USA & & \\
\hline OpV1 & DBG80 & MN099967 & 4 & $\begin{array}{l}\text { Cylindropuntia } \\
\text { echinocarpa }\end{array}$ & 2018 & Arizona, USA & & \\
\hline OpV1 & DBG86 & MN099968 & 4 & \multirow[t]{2}{*}{$\begin{array}{l}\text { Cylindropuntia } \\
\text { spinosior }\end{array}$} & 2018 & Arizona, USA & & \\
\hline OpV1 & DBG_86 & MN099977 & 4 & & 2018 & Arizona, USA & & \\
\hline OpV1 & DBG88 & MN099969 & 4 & $\begin{array}{l}\text { Opuntia cf } \\
\text { polyacantha }\end{array}$ & 2018 & Arizona, USA & & \\
\hline OpV1 & DBG90 & MN099970 & 4 & $\begin{array}{c}\text { Opuntia } \\
\text { phaeacantha }\end{array}$ & 2019 & Arizona, USA & & \\
\hline OpV1 & LCM_85 & MN100016 & 2 & $\begin{array}{l}\text { Opuntia } \\
\text { aureispina }\end{array}$ & 2015 & Texas, USA & & \\
\hline OpV1 & LCM_91_1 & MN100017 & 14 & \multirow[t]{2}{*}{$\begin{array}{c}\text { Cylindropuntia } \\
\text { arbuscula }\end{array}$} & 2015 & Arizona, USA & \multirow{2}{*}{\multicolumn{2}{|c|}{ OpV1 sg-7 }} \\
\hline OpV1 & LCM_91_2 & MN100018 & 15 & & 2015 & Arizona, USA & & \\
\hline OpV1 & S18_1 & MN099978 & 13 & $\begin{array}{c}\text { Opuntia } \\
\text { engelmannii }\end{array}$ & 2018 & Arizona, USA & & \\
\hline OpV1 & S18_8 & MN099979 & 4 & $\begin{array}{c}\text { Opuntia } \\
\text { santa-rita }\end{array}$ & 2018 & Arizona, USA & & \\
\hline OpV1 & S18_89 & MN099980 & 8 & $\begin{array}{c}\text { Opuntia } \\
\text { engelmannii }\end{array}$ & 2018 & Arizona, USA & & \\
\hline OpV1 & TM_cacti_2_1 & MN100037 & 9 & \multirow[t]{2}{*}{$\begin{array}{c}\text { Opuntia } \\
\text { engelmannii. }\end{array}$} & 2018 & Arizona, USA & & \\
\hline OpV1 & TM_cacti_2_2 & MN100038 & 9 & & 2018 & Arizona, USA & & \\
\hline OpV1 & SI_0_1 & MN100019 & 6 & \multirow[t]{4}{*}{ Dactylopius sp. } & 2017 & Arizona, USA & & \\
\hline OpV1 & SI_0_2 & MN100020 & 6 & & 2017 & Arizona, USA & & \\
\hline OpV1 & SI_0_3 & MN100021 & 6 & & 2017 & Arizona, USA & & \\
\hline OpV1 & SI_0_4 & MN100022 & 6 & & 2017 & Arizona, USA & & \\
\hline
\end{tabular}


Table 1. Cont

\begin{tabular}{|c|c|c|c|c|c|c|c|c|}
\hline Virus & Isolate & $\begin{array}{l}\text { Accession } \\
\text { Number }\end{array}$ & Genotype & Host species & Sampling Year & $\begin{array}{l}\text { Region of } \\
\text { Collection }\end{array}$ & $\begin{array}{c}\text { Associated } \\
\text { Insect Samples }\end{array}$ & Sub/Super-Genomic \\
\hline OpV1 & SI_1_1 & MN100023 & 4 & \multirow[t]{4}{*}{ Dactylopius sp. } & 2017 & Arizona, USA & \multirow[t]{4}{*}{ DBG14 } & \\
\hline OpV1 & SI_1_2 & MN100024 & 4 & & 2017 & Arizona, USA & & \\
\hline OpV1 & SI_1_3 & MN100025 & 4 & & 2017 & Arizona, USA & & \\
\hline OpV1 & SI_1_4 & MN100026 & 4 & & 2017 & Arizona, USA & & \\
\hline OpV1 & SI_7_1 & MN100027 & 6 & \multirow[t]{3}{*}{ Dactylopius sp. } & 2017 & Arizona, USA & \multirow[t]{3}{*}{ Cacti 2} & \\
\hline OpV1 & SI_7_2 & MN100028 & 6 & & 2017 & Arizona, USA & & \\
\hline OpV1 & SI_7_3 & MN100029 & 6 & & 2017 & Arizona, USA & & \\
\hline OpV1 & SI_9_1 & MN100030 & 6 & \multirow[t]{2}{*}{ Dactylopius sp. } & 2017 & Arizona, USA & & \\
\hline OpV1 & SI_9_2 & MN100031 & 6 & & 2017 & Arizona, USA & & \\
\hline OpV1 & SI_23 & MN100032 & 11 & Dactylopius sp. & 2018 & Arizona, USA & & \\
\hline OpV1 & SI_28 & MN100033 & 1 & Dactylopius sp. & 2018 & Arizona, USA & & \\
\hline OpV1 & SI_33 & MN100034 & 2 & Dactylopius sp. & 2018 & Arizona, USA & DBG34 & OpV1 sg-9 \\
\hline OpV1 & SI_35 & MN100035 & 11 & Dactylopius sp. & 2018 & Arizona, USA & DBG36 & \\
\hline \multirow[t]{5}{*}{ OpV1 } & SI_39 & MN100036 & 12 & Dactylopius sp. & 2018 & Arizona, USA & & \\
\hline & DBG_28 & & & $\begin{array}{c}\text { Opuntia } \\
\text { spinosibacca }\end{array}$ & 2018 & Arizona, USA & & OpV1 sg-14 \\
\hline & DBG_69 & & & Opuntia rufida & 2018 & Arizona, USA & & OpV1 sg-13 \\
\hline & \multirow[t]{2}{*}{ S18_9 } & & & \multirow[t]{2}{*}{$\begin{array}{l}\text { Opuntia } \\
\text { santa-rita }\end{array}$} & \multirow[t]{2}{*}{2018} & \multirow[t]{2}{*}{ Arizona, USA } & & OpV1 sg-10 \\
\hline & & & & & & & & OpV1 sg-11 \\
\hline
\end{tabular}


Pairwise identity comparisons of OpV1 sequences to those of other known geminiviruses demonstrated that they all share $<64.9 \%$ genome identity with other known geminiviruses, and that all the OpV1 sequences share $>78.4 \%$ identity with one another (Supplementary Data 2 and 3).

OpV1 sequences all contain at least six recognizable open reading frames (ORFs) that were both capable of encoding proteins with $>198$ amino acids, and which shared some detectable similarity with known geminivirus-expressed proteins. If these ORFs are indeed genes, then the genome organization of the OpV1 sequences resembles that of viruses in the genus Begomovirus with monopartite genomes. On the presumed complementary strand, the OpV1 sequences potentially encode a replication-associated protein (Rep), a replication enhancer protein (Ren), a transactivation protein (TrAP) and a symptom determinant protein (C4) (Figure 1). A likely capsid protein (CP) and a possible movement protein (MP) are encoded on the virion strand. Within the OpV1 sequences, in the area corresponding to an intergenic region, there is a conserved nonanucleotide motif, "TAATATTAC", contained within a likely stem-loop structure which, by analogy with other geminiviruses, is the likely site where virion strand replication is initiated (Figure 1). Within the intergenic region, we identified replication-associated iterative sequences "iterons", the TATA box and conserved late element (CLE)-like sequences (Figure 1). There were two discernible iterons among most OpV1 isolates: a direct repeat adjacent to the rep gene TATA box, and an inverse repeat situated 41-42 nt upstream the TATA box. However, in a few OpV1 isolates, two in-tandem iterons are associated with the rep TATA box, similar to iterons observed in New World begomoviruses [78]. The specific sequence of the iterons also varied among OpV1 isolates, predominating those with a GGGTCC core sequence, although repeated elements with either GGTGCC, GGAGTC, GGTATY, or GGTGTC core sequences, among others, were also identified in some OpV1 isolates (Figure 1). The functional relevance of those differences is currently unknown. Another OpV1 feature is the position of the TATA box immediately adjacent to the ori stem-loop element (Figure 1), a unique arrangement among the geminiviruses.

As with the OpV1 nucleotide sequences, the amino acid sequences of the individual proteins that are likely encoded by these sequences display a considerable amount of diversity. Even the most conserved of these, $\mathrm{CP}$ and Rep, respectively, have pairwise amino acid sequence identities that are as low as $74.3 \%$ and $77.1 \%$ between different isolates.

Based on the distribution of pairwise nucleotide sequence identities shared by the $79 \mathrm{OpV} 1$ sequences, a 95\% sequence identity threshold was selected as a cut-off for defining distinct OpV1 genetic groupings. Applying this threshold to sub-classify the OpV1 sequences yielded 15 genotype groupings (Table 1).

It is noteworthy that, out of the 13 instances where more than one OpV1 sequence was isolated from a given plant sample, in seven cases the $\mathrm{OpV} 1$ sequences belonged to different genotype groups, i.e., in $>50 \%$ of instances where two different sequences were sampled from the same plant, these two sequences shared $<95 \%$ pairwise identity (Table 1 ). In three out of five instances where OpV1 sequences were retrieved from insects that were sampled on a plant from which OpV1 sequences were retrieved, the sequences in the insects were assigned to different genotypes than those to which the sequences in the plants were assigned.

Phylogenetic analysis of the full-length genome of OpV1 genotypes with representative geminivirus genome sequences (i.e., including representatives of the nine established geminivirus genera and other geminiviruses that have not yet been assigned to a genus) indicated that the OpV1 sequences could justifiably be assigned to a new geminivirus genus (Figure 1). The OpV1 sequences are most closely related to begomoviruses, topocuvirus and the unassigned geminiviruses Polygala garcinii associated virus (MG001959), apple geminivirus, (KM386645), Juncus maritimus associated virus (MG001958), and grapevine geminivirus A (KX618694). 


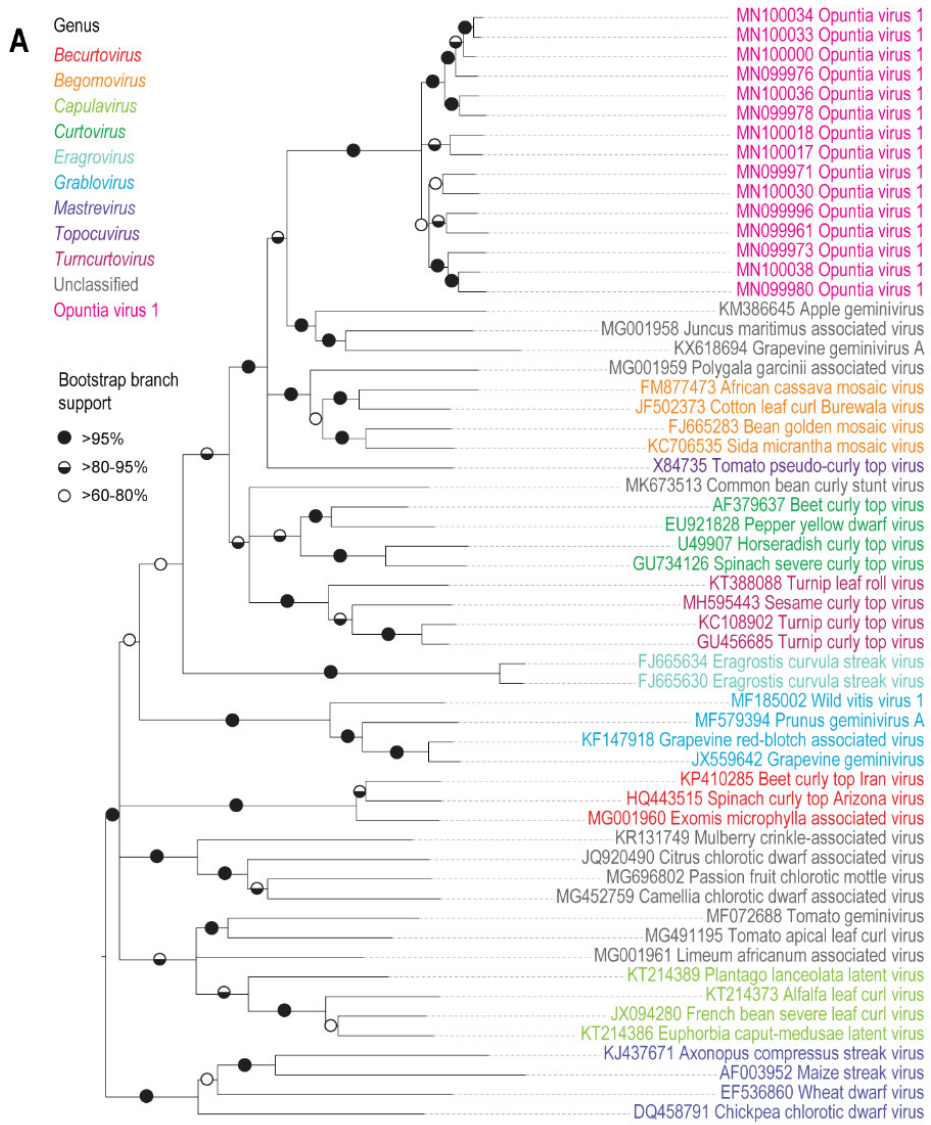

$\overline{0.07}$ nucleotides sub per site

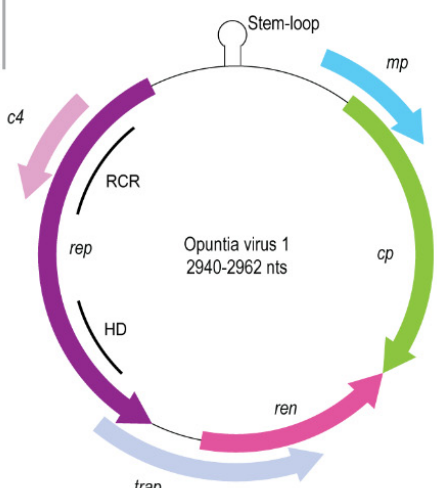

trap

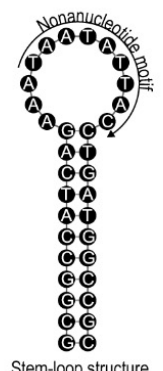

B

MN100033_Gen MN100034_Gen2 MN099976_Gen3 MN100000_Gen4 MN099961_Gen5 MN100030_Gen6 MN099973_Gen7 MN099980_Gen8 MN100038_Gen9 MN099971_Gen10 MN099996_Gen1 MN100036_Gen12 MN099978_Gen1 MN100017_Gen1 MN100018_Gen15

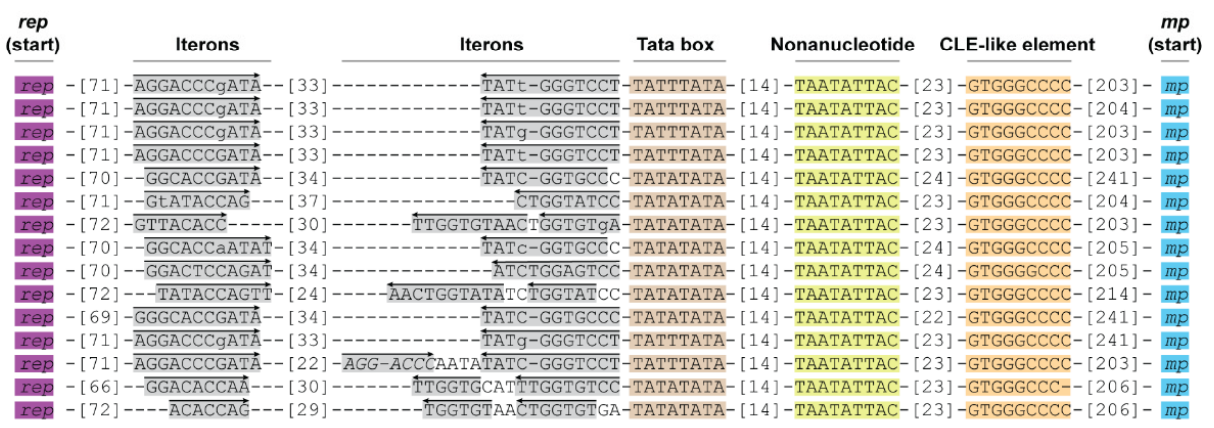

C

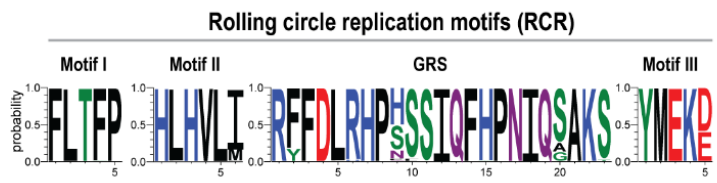

Figure 1. (A). Neighbor-Joining phylogenetic tree of the full-length genome of representatives of the 15 genotypes of OpV1 with those of the family Geminiviridae. Branches with $<60 \%$ bootstrap support are collapsed, and the tree is midpoint-rooted. The genomic organization of OpV1 and the stem-loop structure containing the nonanucleotide motif are shown to the right of the phylogenetic tree. (B). Nucleotide sequence and organization of origin of replication-associated iterative sequences "iterons" in the intergenic region. Arrows indicate the orientation of the iterons with respect to the nonanucleotide sequence. Lower-case letters in an iterated element indicate a nucleotide that does not match in all the iterons from OpV1 viruses of that same genotype. The TATA box, nonanucleotide motif and conserved late element (CLE)-like sequence. (C). Graphic representation of the variation in amino acids in the motifs from the SF3 helicase domains and the rolling circle replication motifs present in the Rep sequences of the 79 OpV1s. 
Similarly, phylogenetic analysis of the predicted OpV1 Rep amino acid sequences, together with those of representative geminiviruses, indicated that the OpV1 Rep sequences are most closely related to those of begomoviruses, curtoviruses, topocuviruses, turncurtoviruses and the unclassified geminiviruses common bean curly stunt virus (MK673513); Polygala garcinii associated virus (MG001959); apple geminivirus (KM386645); Juncus maritimus associated virus (MG001958) and grapevine geminivirus A (KX618694) (Figure 2). The OpV1 Rep amino acid sequences share $<68.2 \%$ identity with those of other geminiviruses.

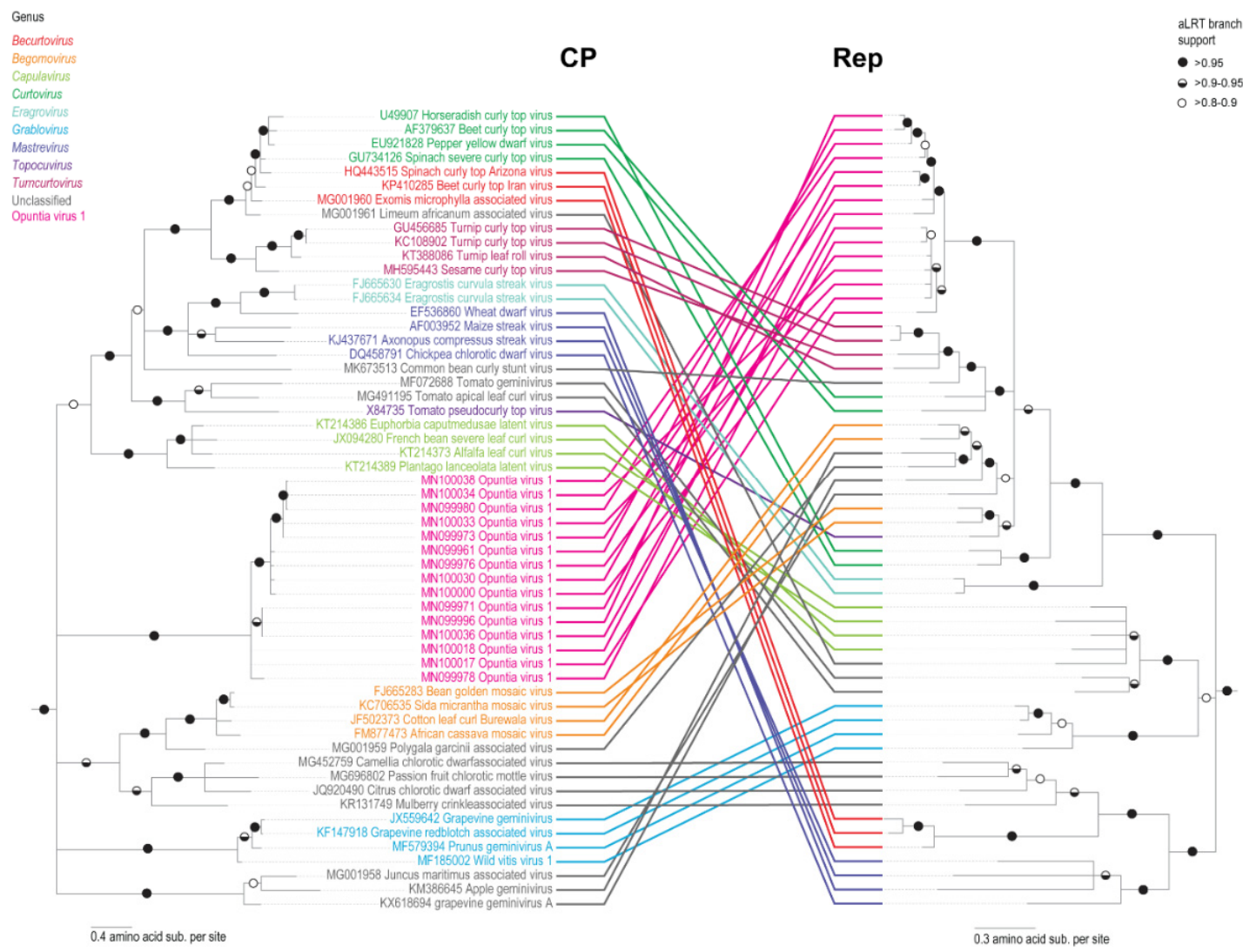

Figure 2. Maximum Likelihood (ML) phylogenetic trees of the Rep and CP amino acid sequences of the representative 15 genotypes of OpV1 together with other geminiviruses. Branches with aLRT support $<0.8$ are collapsed and both trees were rooted with genomovirus [79] sequences.

The predicted OpV1 Rep amino acid sequences all contain predicted rolling circle replication, GRS, SF3 and Walker motifs that are similar to those found in other geminiviruses [80]. It is noteworthy that there is variability within these Rep motifs across the different predicted OpV1 Rep amino acid sequences, which further emphasizes the diversity within this group of viruses (Figure 1).

Unlike with the Rep amino acid sequences, the predicted OpV1 CP amino acid sequences group phylogenetically within a divergent clade (Figure 2). This is likely a consequence of the OpV1 CP amino acid sequences sharing $<28.9 \%$ amino acid identity with those of other geminiviruses. Recently, phylogenetic evidence that the CP amino acid sequences of geminiviruses are possibly co-diverging with their specific insect vectors has emerged [81]. A sequence similarity network analysis of the CP amino acid sequence of all geminiviruses (with a $>90 \%$ identity cut-off) was generated and the association of the known geminivirus CPs with known insect vectors is summarized in Figure 3 . It is clear that, whenever geminiviruses share an insect vector, their $\mathrm{CP}$ amino acid sequences cluster together. As expected, given the divergence of OpV1 CP amino acid sequences relative to those of other geminiviruses, these sequences form their own cluster, implying that they are likely to be transmitted by an insect species that has not previously been associated with geminivirus transmission. Given 
the association of cochineal insects with the cactus plants from which OpV1 sequences were isolated and the direct isolation of OpV1 sequences from some of these insects, it remains plausible that these insects may be OpV1 transmission vectors. However, controlled insect transmission experiments will be needed to properly test this hypothesis.
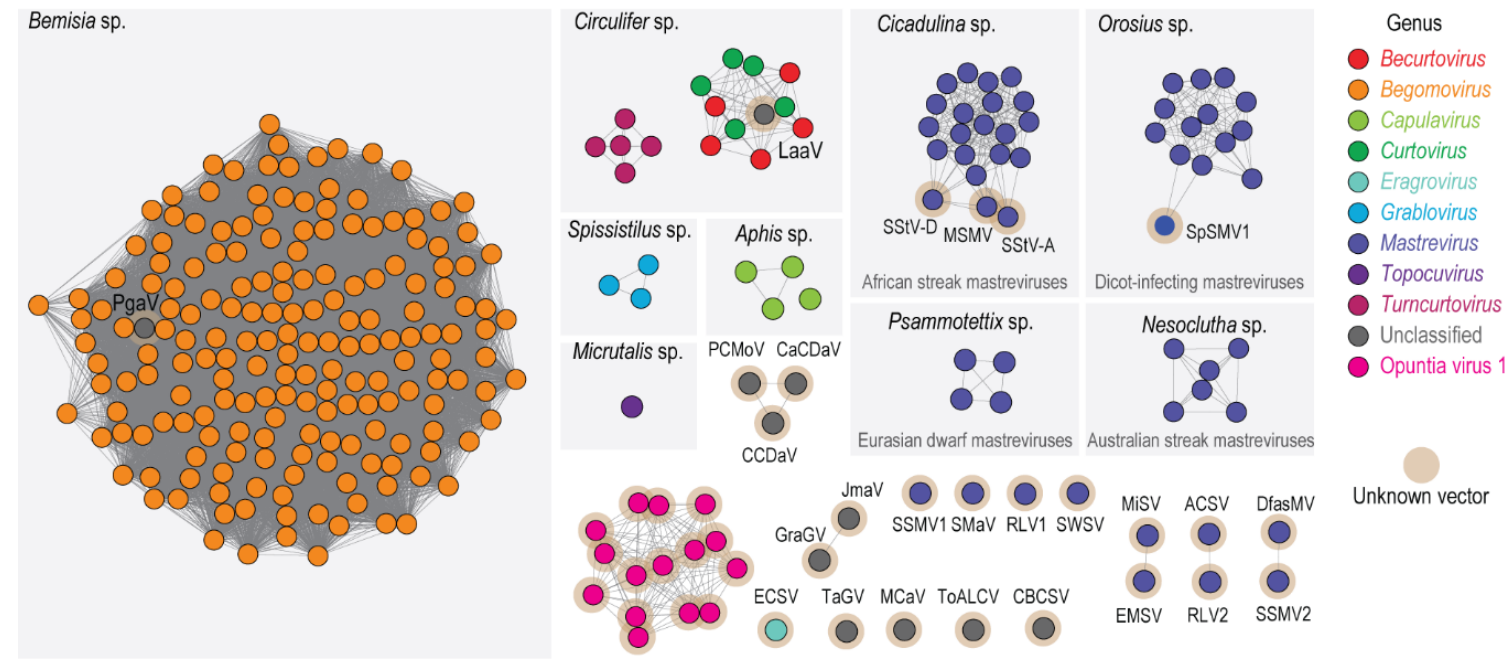

Figure 3. Sequence similarity network analysis of the $\mathrm{CP}$ amino acid sequences of representatives of the 15 genotypes from OpV1, together with those of the geminiviruses present in GenBank (dataset was created with an amino acid identity cut-off of 90\%). The clusters are colored based on the genus or group. The genera that have known insect vectors are highlighted in a light grey box with the insect vector name displayed in the top. Clusters or singletons marked with a brown halo have no known insect vector associated with them. ACSV, Axonopus compressus streak virus; $\mathrm{CaCDaV}$, Camellia chlorotic dwarf-associated virus; $\mathrm{CCDaV}$, Camellia citrus chlorotic dwarf-associated virus; DfasMV, dragonfly-associated mastrevirus; CBCSV, common bean curly stunt virus; ECSV, Eragrostis curvula streak virus; EMSV, Eragrostis minor streak virus; GraGV, grapevine geminivirus; JmaV, Juncus maritimus-associated virus; LaaV, Limeum africanum-associated virus; MCaV, mulberry crinkleassociated virus; MiSV, Miscanthus streak virus; MSMV, maize streak Reunion virus; PCMoV, passion fruit chlorotic mottle virus; PgaV, Polygala garcinii-associated virus; RLV1, rice latent virus 1; RLV2, rice latent virus 2; SMaV, switchgrass mosaic-associated virus; SpSMV1, sweetpotato symptomless mastrevirus 1; SSMV1, Sporobolus striate mosaic virus 1; SSMV2, Sporobolus striate mosaic virus 2; SStV-A, sugarcane striate virus A; SStV-D, sugarcane striate virus D; SWSV, sugarcane white streak virus; TaGV, tomato-associated geminivirus; ToALCV, tomato apical leaf curl virus.

The high degree of nucleotide sequence diversity amongst the OpV1 sequences suggests, assuming a similar rate of nucleotide sequence diversification to that seen in other geminiviruses, that OpV1 has likely been circulating in the USA for more than 600 years, i.e., the approximate time it would take mastrevirus and begomovirus species to achieve the degree of diversity observed for the OpV1 sequences [82-87]. The lower numbers of OpV1-positive samples found outside the USA certainly represents a sampling bias. Although the number of OpV1-positive cactus plants originating from Mexico were very low (2/31 tested plants), this $6.4 \%$ prevalence is not substantially different to the $7.4 \% \mathrm{OpV} 1$ prevalence in cactus samples from the USA.

\subsection{Testing the Infectivity of the Novel Cactus-Infecting Geminiviruses}

To assess the infectivity of OpV1, a Rhizobium-infectious clone was created using the isolate DBG_14_1 (MN100000). The infectious clone was generated using 1.9 unit length DBG_14_1 sequences cloned tandem within the pGTV-kan binary vector [60]. Rhizobium-mediated inoculation assays were performed on plants of $N$. benthamiana, O. ficus-indica, O. microdasys, O. engelmannii and O. santa-rita. The experiments with $N$. benthamiana were carried out in triplicate, with two replicates 
consisting of 18 inoculated plants and the third of seven inoculated plants; two negative control (non-inoculated) plants were included in all experiments. The rate of infection in N. benthamiana plants varied between replicates. In the initial experiment, five out 18 plants were positive for OpV1 infection and systemic viral infection could be detected at 5 days post inoculation (dpi). In the second experiment, 10 out of 18 plants were positive for OpV1, with systemic viral infection also being detectable at $5 \mathrm{dpi}$. In the third experiment, samples were only evaluated at $21 \mathrm{dpi}$ and they were all positive for OpV1 by PCR. The Southern blot analysis of the third infectivity assay of Rhizobium-mediated OpV1-infected N. benthamiana plants corroborated with the PCR results, showing the viral DNA replicative forms in all seven inoculated plants (open circular, linear, covalent closed circular and single stranded) and no viral infection in the negative controls (Supplementary Figure S1). We also observed geminate particles in the viral extract of the Rhizobium-mediated OpV1 infected N. benthamiana leaves (Supplementary Figure S1). In the inoculation assays with O. ficus-indica, O. microdasys, O. engelmannii and O. santa-rita, five plants (one individual pad) from each species were Rhizobium-infiltrated and one plant was kept as a negative control (non-inoculated). Cacti are perennial plants that have slow growth rates, and it is therefore difficult to assess systemic infection. From the inoculated cactus species, only O. ficus-indica and O. microdasys plants developed new pads over the course of the experiment ( $\sim 8$ months). Wherever new pads were unavailable for sampling, the area of sampling in the originally inoculated pad was selected to be as distant as possible from the spot where the Rhizobium-inoculation was carried out. Of the 16 Opuntia plants inoculated with OpV1, only one, an individual of O. microdasys, was positive for OpV1 by PCR five months post-inoculation.

No symptoms associated with viral infection were observed in either N. benthamiana or O. microdasys. Infections were further confirmed by recovering viral genomes (which were cloned and sequenced; Supplementary Data 4) from the non-inoculated leaves of five N. benthamiana OpV1 positive plants and one OpV1 positive O. microdasys plant.

\subsection{Evolutionary Dynamics of the Novel Divergent Geminivirus Group}

Given that genetic recombination has been found to occur frequently during the evolution of other geminiviruses and that recombination has been implicated in the genesis of at least four of the currently recognized geminivirus genera $[43,46,88-96]$, we examined the OpV1 sequences for evidence of recombination. In total, we detected 23 well-supported recombination events during the evolution of the $79 \mathrm{OpV} 1$ sequences from their most recent common ancestor. The sizes of genome fragments transferred during these recombination events ranged from approximately 64 to $1171 \mathrm{nt}$ (Table 2). Except for the only sequence belonging to genotype 8, all the sequences displayed well supported evidence of at least one recombination event. Some of the OpV1 sequences assigned to genotype 12 display evidence of at least five distinct recombination events. While some of the detected recombination events appear to have occurred quite recently, in that they were only detectable within single OpV1 sequences, others, such as one event that is detectable in all of the genotype 1, 2, 12 and 13 sequences, likely occurred in the more distant past, i.e., prior to the time when the most recent common ancestors of the sequences, sharing evidence of the recombination events, existed.

The largest genome fragment transferred during the detected recombination events was seen in the genotype 6 sequences, and involved the transfer of the $\sim 40 \%$ of the genome spanning the intergenic region and the virion strand protein-coding genes.

As has been previously noted for other geminiviruses [95-98], a high proportion of the detected recombination events have breakpoints in the intergenic region at or close to the presumed virion strand origin of replication. Similar to breakpoint patterns seen in other geminiviruses, the Rep/AC4 region of the genome appears to be the genome site outside the intergenic region where recombination breakpoints most frequently occur (Figure 4). Conversely, the region of the genome spanning the ren and trap genes appears to have the lowest frequency of detectable recombination breakpoints. 
Table 2. Summary of the 23 events of recombination detected by RDP4. The methods used to detect recombination are RDP (R) GENCONV (G), BOOTSCAN (B), MAXCHI (M), CHIMERA (C), SISCAN (S) and 3SEQ (T). The method with the highest $p$-value for each recombination event is bolded. Sites where the actual breakpoint is undetermined are marked with *. (tr) denotes trace of recombination signal.

\begin{tabular}{|c|c|c|c|c|c|c|}
\hline Recombination Event & Region & $\begin{array}{l}\text { Recombinant } \\
\text { Sequence(s) }\end{array}$ & $\begin{array}{c}\text { Minor Parental } \\
\text { Sequence(s) }\end{array}$ & $\begin{array}{l}\text { Major Parental } \\
\text { Sequence(s) }\end{array}$ & $\begin{array}{l}\text { Detection } \\
\text { Methods }\end{array}$ & $p$-Value \\
\hline 1 & $2156-4$ & Genotype 12 & Genotype 2 & Genotype 11 & RGBMCST & $1.41 \times 10^{-69}$ \\
\hline 2 & $1915-2$ & Genotype 1 & Genotype 4 & Genotype 7 & RGBMCST & $4.11 \times 10^{-56}$ \\
\hline 3 & $2338-2878$ & Genotype 14 & $\begin{array}{l}\text { Genotype } 2 \\
\text { Genotype } 7\end{array}$ & Genotype 15 & RBMCS & $1.74 \times 10^{-34}$ \\
\hline 4 & $2066-42$ & Genotype 2 & Genotype 4 & $\begin{array}{l}\text { Genotype } 9 \\
\text { Genotype } 7\end{array}$ & RGBMCS & $9.95 \times 10^{-39}$ \\
\hline 5 & 2088-2961 & $\begin{array}{c}\text { Genotype } 11 \\
\text { Genotype } 12(\mathrm{tr})\end{array}$ & $\begin{array}{l}\text { Genotype } 8 \\
\text { Genotype } 5\end{array}$ & Genotype 10 & RGBMCS & $6.08 \times 10^{-29}$ \\
\hline 6 & 2304-2819 & Genotype 10 & Genotype 6 & Genotype 11 & RGBMCST & $1.08 \times 10^{-24}$ \\
\hline 7 & $2301-2844$ & $\begin{array}{c}\text { Genotype } 15 \\
\text { Genotype } 14(\operatorname{tr})\end{array}$ & Genotype 7 & $\begin{array}{c}\text { Genotype } 11 \\
\text { Genotype } 4\end{array}$ & RGBMCS & $4.94 \times 10^{-17}$ \\
\hline 8 & 2333-2939 & Genotype 13 & Genotype 4 & $\begin{array}{l}\text { Genotype } 11 \\
\text { Genotype } 7\end{array}$ & RGBMCS & $7.33 \times 10^{-29}$ \\
\hline 10 & $1582-1765$ & $\begin{array}{l}\text { Genotype } 3 \\
\text { Genotype } 1 \\
\text { Genotype } 7\end{array}$ & Genotype 13 & $\begin{array}{l}\text { Genotype } 2 \\
\text { Genotype } 4\end{array}$ & RBCS & $2.05 \times 10^{-13}$ \\
\hline 11 & $2860-2946$ & Genotype 10 & Genotype 6 & Genotype 11 & RGMCST & $2.04 \times 10^{-10}$ \\
\hline 12 & $2928-1156$ & Genotype 6 & $\begin{array}{l}\text { Genotype } 4 \\
\text { Genotype } 3\end{array}$ & $\begin{array}{l}\text { Genotype } 9 \\
\text { Genotype } 11 \\
\text { Genotype } 13 \\
\text { Genotype } 12\end{array}$ & RBMCS & $6.50 \times 10^{-26}$ \\
\hline
\end{tabular}


Table 2. Cont

\begin{tabular}{|c|c|c|c|c|c|c|}
\hline Recombination Event & Region & $\begin{array}{l}\text { Recombinant } \\
\text { Sequence(s) }\end{array}$ & $\begin{array}{c}\text { Minor Parental } \\
\text { Sequence(s) }\end{array}$ & $\begin{array}{c}\text { Major Parental } \\
\text { Sequence(s) }\end{array}$ & $\begin{array}{l}\text { Detection } \\
\text { Methods }\end{array}$ & $p$-Value \\
\hline 13 & $514-1166$ & Genotype 5 & $\begin{array}{l}\text { Genotype } 4 \\
\text { Genotype } 3\end{array}$ & Genotype 11 & RGBMCS & $6.12 \times 10^{-18}$ \\
\hline 14 & $31 *-512$ & $\begin{array}{c}\text { Genotype } 10 \\
\text { Genotype } 12(\mathrm{tr}) \\
\text { Genotype } 11(\mathrm{tr})\end{array}$ & $\begin{array}{l}\text { Genotype } 3 \\
\text { Genotype } 7\end{array}$ & $\begin{array}{l}\text { Genotype } 14 \\
\text { Genotype } 9\end{array}$ & RBMC & $4.05 \times 10^{-9}$ \\
\hline 15 & $1494^{*}-1866$ & Genotype 5 & Genotype 6 & $\begin{array}{l}\text { Genotype } 11 \\
\text { Genotype } 10 \\
\text { Genotype } 12\end{array}$ & RGBMCST & $2.93 \times 10^{-10}$ \\
\hline 16 & $2332-2719$ & $\begin{array}{c}\text { Genotype } 4 \\
\text { Genotype } 13 \\
\text { Genotype } 2 \\
\text { Genotype } 12 \\
\text { Genotye } 1\end{array}$ & Unknown & Genotype 6 & RGBMCST & $1.88 \times 10^{-32}$ \\
\hline 17 & $30 *-489$ & Genotype 13 & Genotype 3 & $\begin{array}{l}\text { Genotype } 14 \\
\text { Genotype } 15\end{array}$ & GBMCST & $9.73 \times 10^{-9}$ \\
\hline 19 & $1791-1855$ & $\begin{array}{c}\text { Genotype } 10 \\
\text { Genotype } 13(\mathrm{tr})\end{array}$ & Genotype 2 & $\begin{array}{l}\text { Genotype } 12 \\
\text { Genotype } 11\end{array}$ & GBT & $9.66 \times 10^{-6}$ \\
\hline 20 & $27-373$ & Genotype 3 & $\begin{array}{l}\text { Genotype } 7 \\
\text { Genotype } 1\end{array}$ & Genotype 4 & RBMCT & $5.80 \times 10^{-6}$ \\
\hline 21 & $2445^{*}-2543$ & $\begin{array}{l}\text { Genotype } 15 \\
\text { Genotype } 7\end{array}$ & $\begin{array}{l}\text { Genotype } 11 \\
\text { Genotype } 8\end{array}$ & Unknown & RGBC & $1.77 \times 10^{-05}$ \\
\hline 22 & $1881-26^{*}$ & $\begin{array}{c}\text { Genotype } 12 \\
\text { Genotype } 11(\mathrm{tr})\end{array}$ & Genotype 4 & $\begin{array}{l}\text { Genotype } 14 \\
\text { Genotype } 15\end{array}$ & GBMCST & $8.71 \times 10^{-5}$ \\
\hline 23 & $1132-1462$ & $\begin{array}{l}\text { Genotype } 15 \\
\text { Genotype } 14\end{array}$ & Unknown & $\begin{array}{l}\text { Genotype } 12 \\
\text { Genotype } 11\end{array}$ & MCT & $5.90 \times 10^{-3}$ \\
\hline
\end{tabular}




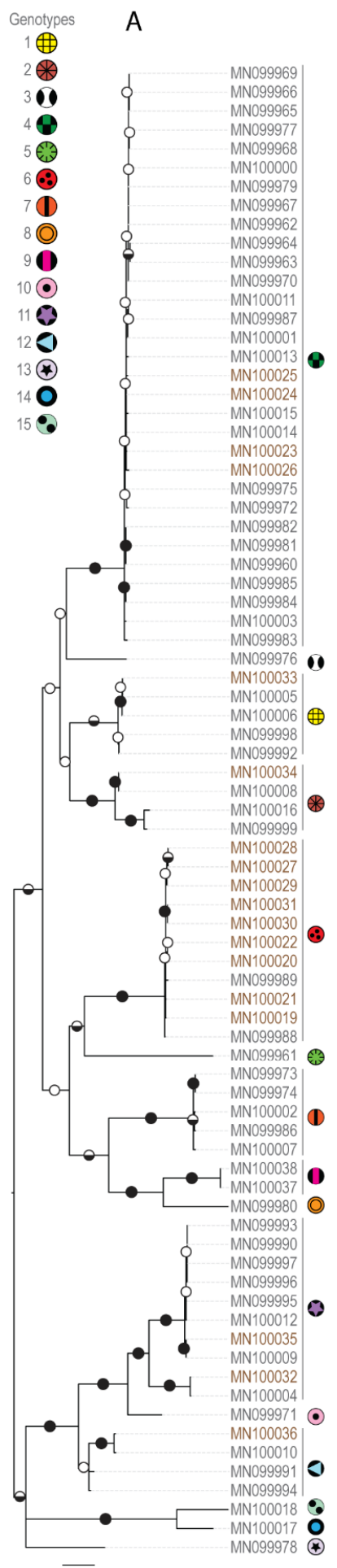

$\overline{0.02}$ nucleotide sub. per site
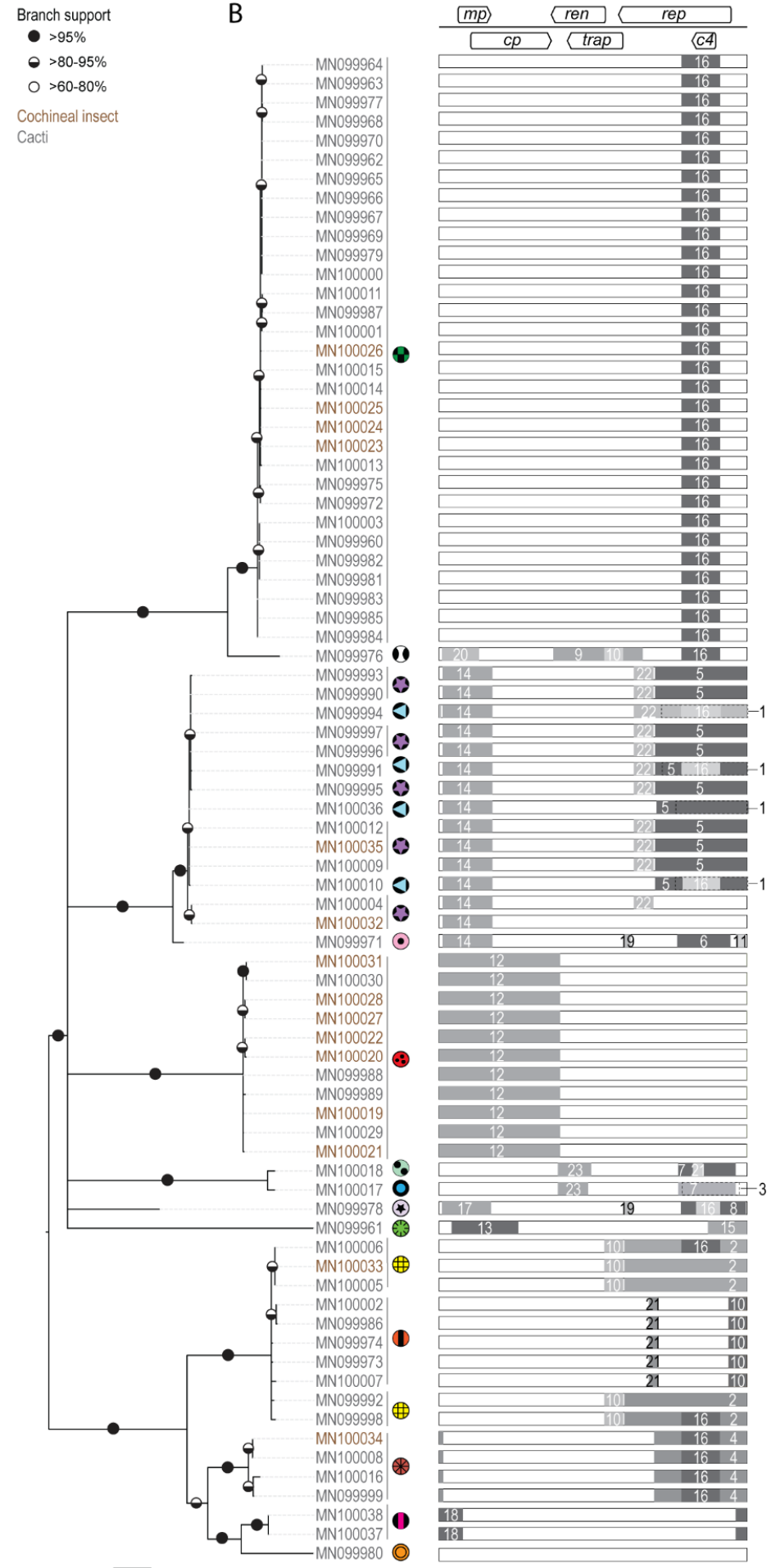

$\overline{0.03}$ nucleotide sub. per site

Figure 4. (A). Neighbor-Joining phylogenetic tree of the 79 OpV1 genomes recovered in this study. Branches with $<60 \%$ bootstrap support are collapsed. (B). Maximum Likelihood phylogenetic tree of the 79 OpV1 genomes with recombination regions removed. For each genome, a graphic on the right indicates the recombination event with its breakpoint location within the genome. Branches with $<60 \%$ bootstrap support are collapsed. The 15 genotypes are marked with symbols and genomes that have been recovered from plants (accession numbers in grey) and cochineal insects (accession numbers in brown) are indicated. 


\subsection{Identification of Sub/Super-Genomic Molecules}

It is noteworthy that during attempts to clone OpV1 sequences, we recovered 12 apparently sub-genome length clones containing OpV1 sequences from nine cactus plants and one cochineal insect (OpV1 sg 9) (Figure 5), as well as a sequence containing a full complement of OpV1 DNA together with a $238 \mathrm{nt}$ long sequence insert of unknown origin (i.e., super-genome length) from one cactus plant (OpV1 sg 2). The presence of similar sub-genome length geminivirus-derived DNA within geminivirus infections, commonly referred to as sub-genomic molecules, have been extensively reported elsewhere [27,99-106]. In addition to deletions, in some cases sub-genomic molecules have also been found to contain sequence insertions, duplications and inversions $[103,107,108]$. The conservation within sub-genomic molecules of intergenic region sequences-the portion of geminivirus genomes containing the origin of virion-strand replication-indicates that these molecules are, in many cases, potentially either self-replication-competent (if they contain an intact rep gene) or are capable of being trans-replicated by non-defective viruses [109].
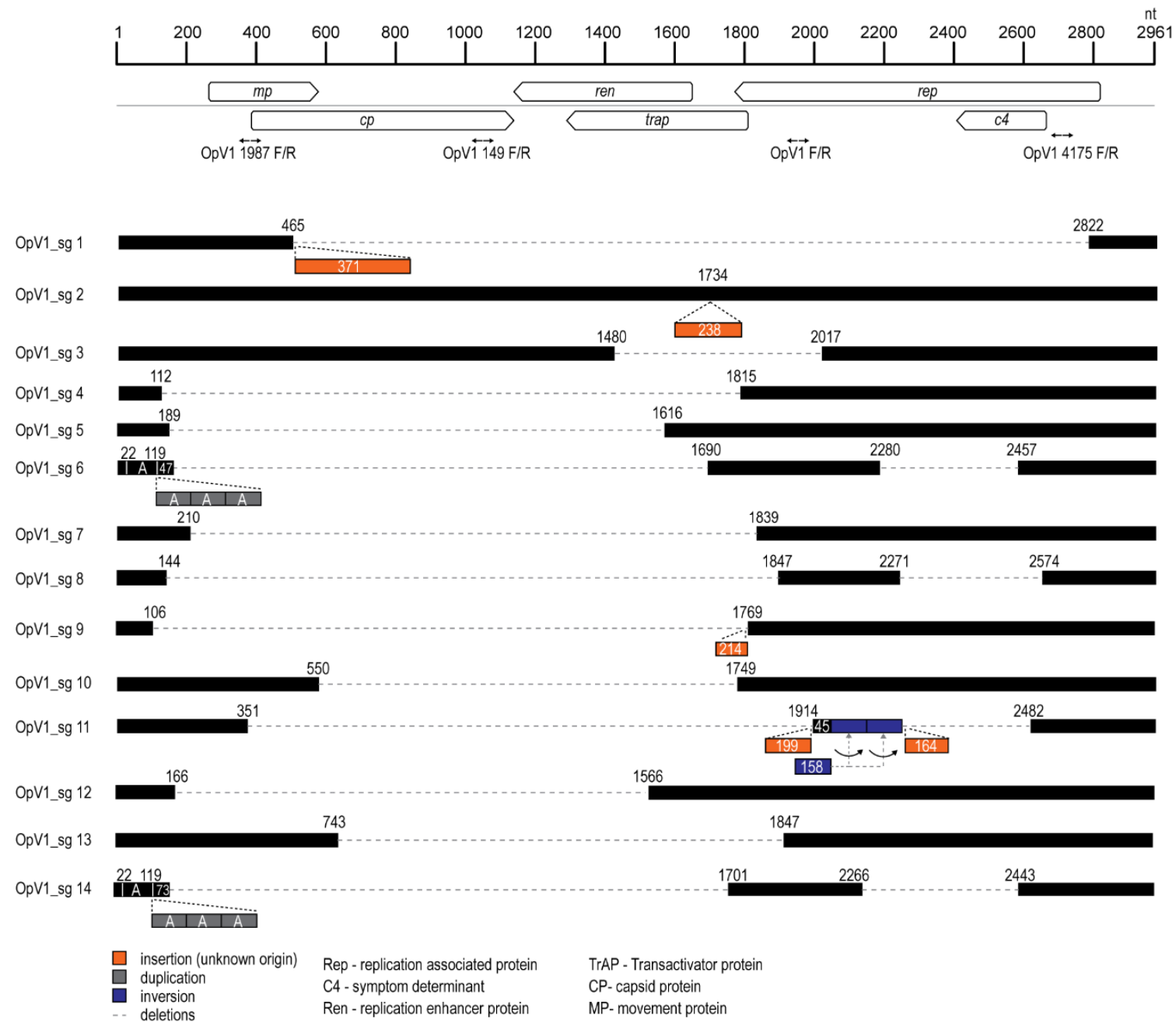

Figure 5. Structure of OpV1 sub/super-genomic molecules in comparison to an OpV1 parental full-length genome. The areas where deletion occurred are presented by dotted grey lines, insertions, inversions and duplications are represented by orange, blue and grey boxes respectively. The primers pairs used to obtain the sub/super-genomic molecules are shown at their respective binding sites on the parental full-length genome.

From the three cactus samples that we examined (one each of O. spinosibacca, O. rufida and O. santa-rita), we were only able to recover sub-genomic molecules (Table 1 ). None of these sub-genomic 
molecules (OpV1 sg 10, -11, -13 and -14; Figure 5) had a rep gene without disruption, which indicates that they would have needed to be trans-replicated by either a non-defective OpV1 variant or some other geminivirus.

OpV1 sg 6 and -14, which were each recovered from different cactus plants, displayed an interesting similarity. Both contain three tandem repeats of the portion of the intergenic region between 22 and $119 \mathrm{nt}$ upstream of the presumed virion strand origin of replication (Figure 5). OpV1 sg 6, -8, -11 and -14 all have a similar domain deleted within the Rep coding region (Figure 5). The deletions in the Rep-coding region in these molecules are such that the N-terminus of the Rep amino acid sequence has at least two intact rolling circle replication motifs (motif I and II). OpV1 sg 6, -8 and -14 have a second ORF that has an in-frame C-terminus with two helicase motifs (Walker B and motif C). Furthermore, all OpV1 sg molecules except sg 2 and -3 have a deletion spanning the region (743-1566 nt) that encodes the CP, Ren and TrAP proteins (Figure 5).

Only three of the 14 sub-genomic molecules (OpV1 sg 2, -5, and -12) have an intact Rep coding region and only two have an intact $\mathrm{CP}$ coding region (OpV1 sg 2 and -3 ).

OpV1 sg 2, is larger than the predicted full-length genome of OpV1 with an insert of $238 \mathrm{nt}$ of unknown origin (we have labelled this as super-genomic molecule), and has all coding regions intact, except that encoding the Ren protein (Figure 5). Insertions of unknown origin are in OpV1 sg 1 (371 nt), OpV1 sg 9 (214) and OpV1 sg 11 (199/164 nt). In a recent study on beets (Beta vulgaris) infected with the geminivirus beet curly top Iran virus (BCTIV), circular molecules labelled as "minicircles" were identified containing large AT-rich host derived sequences, as well as the BCTIV intergenic region containing the origin of replication [110]. The minicircles have been proposed to act as a possible mechanism of horizontal gene transfer among host plants. It is important to highlight that the actual diversity of sub/super-genomic DNA molecules that might arise during OpV1 infections is likely higher than those that we have detected here, since the PCR primer binding sites used to amplify these molecules may impact the distributions of the observed deleted regions.

The mechanisms that generate geminivirus sub-genomic molecules are still unclear, although the presence of secondary structures and possible clashes between the replication and transcriptional machinery (due to the bidirectionality of transcription and replication in these viruses) have been suggested as facilitators in this process [111]. Some geminivirus sub-genomic molecules have been shown to be packaged into virions and transmitted by their insect vectors [100,112]; in some cases they can be co-transmitted with their helper/original virus $[103,109]$ which supports our findings of sub-genomic molecules (OpV1 sg 9) along with full-length OpV1 genomes in the cochineal insect (Table 1). The sequence of the sub/super-genomic molecules are provided in Supplementary Data 5.

\section{Concluding Remarks}

OpV1, the first reported cactus-infecting DNA virus, is the latest member of the family Geminiviridae that will likely require assignment to a novel genus. Despite its high degree of divergence relative to other known geminiviruses-particularly in the $\mathrm{CP}-\mathrm{OpV} 1$ has numerous similarities with its nearest geminiviruses relatives. OpV1 has a genome organization that is very similar to that of other geminiviruses; it displays patterns of recombination that mirror those of other geminiviruses, and it forms sub-genomes with patterns of deletion and sequence insertions and rearrangements that are reminiscent of those formed by other geminiviruses.

OpV1 appears to be restricted to the family Cactaceae but has a broad range of host species within the family. In the cactus samples collected to date, no specific host species association to any OpV1 genotype groupings could be inferred. In some cases, we recovered up to five different genotypes from one cactus species and genotype 6 was recovered from 11 different cacti. OpV1 genomes were recovered only from cactus plants in the USA (proportion of plants tested that were positive $7.4 \%$ ) and Mexico (proportion of plants tested that were positive 6.5\%). We were unable to conclusively determine whether cochineal insects are a transmission vector of OpV1, however, it is evident that these insects do acquire the virus upon feeding on infected cactus plants, and therefore it is plausible 
that they could transmit the virus. Additionally, the host range of cochineal insects is restricted to cacti, further supporting their role as vectors of OpV1, which, to date, has only been identified as infecting cacti. This is also well supported by the CP cluster analyses where the OpV1 CPs form a distinct cluster from those geminiviruses with known insect vectors. Further, we were able to show that cloned OpV1 sequences are capable of initiating asymptomatic systemic infections in N. benthamiana and O. microdasys. Although we can only confirm that OpV1 is present in the USA and Mexico, it remains plausible that it occurs in other areas of the Americas or parts of the world where cacti are cultivated for agricultural or ornamental purposes.

Supplementary Materials: Supplementary materials can be found at http://www.mdpi.com/1999-4915/12/4/398/s1.

Author Contributions: Conceptualization, R.S.F. and A.V.; methodology, R.S.F. and A.V.; software, R.S.F., D.P.M and A.V.; validation, R.S.F. and A.V.; formal analysis, R.S.F., J.A.A.-C., G.R.A.-A., D.P.M. and A.V.; investigation, R.S.F., A.M.S., L.C.M., I.N.C., A.B., J.A.A.-C., G.R.A.-A., K.S. (Kara Schmidlin), A.K., K.S. (Kendal Smith), J.S., M.C.L., M.K., M.F.W., W.C.H., R.P.-M., K.V.D., S.K., C.V., D.F., P.R., P.L., S.G.R., S.K., D.P.M., A.V.; resources, R.S.F., A.M.S., L.C.M., I.N.C., A.B, K.S. (Kara Schmidlin), M.C.L., M.K., M.F.W., W.C.H., R.P.-M., K.V.D., S.K., C.V., D.F., P.R., P.L., S.G.R., S.K., D.P.M., A.V.; data curation, R.S.F. and A.V.; writing-original draft preparation, R.S.F., D.P.M. and A.V.; writing-review and editing, R.S.F., A.M.S., L.C.M., I.N.C., A.B., J.A.A.-C., G.R.A.-A., K.S. (Kara Schmidlin), A.K., K.S. (Kendal Smith), J.S., M.C.L., M.K., M.F.W., W.C.H., R.P.-M., K.V.D., S.K., C.V., D.F., P.R., P.L., S.G.R., S.K., D.P.M., A.V.; visualization, R.S.F. and A.V.; supervision, A.M.S., A.V.; project administration, A.V.; funding acquisition, A.V. All authors have read and agreed to the published version of the manuscript.

Funding: The molecular work was supported by a start-up grant awarded to AV from Arizona State University, USA.

Acknowledgments: We thank Stephen Johnston and Luhui Shen from the Biodesign Center for Innovation in Medicine at Arizona State University for the support they provided for biolistic experiments. We thank Life Sciences Electron Microscopy Lab at Arizona State University for the electron microscopy support.

Conflicts of Interest: The authors declare no conflict of interest. The funders had no role in the design of the study; in the collection, analyses, or interpretation of data; in the writing of the manuscript, or in the decision to publish the results.

\section{References}

1. Anderson, E.F. The Cactus Family; Timber Press (OR): Portland, OR, USA, 2001; p. 776.

2. Guerrero, P.C.; Majure, L.C.; Cornejo-Romero, A.; Hernández-Hernández, T. Phylogenetic relationships and evolutionary trends in the Cactus family. J. Hered. 2018, 110, 4-21. [CrossRef] [PubMed]

3. Hernandez-Hernandez, T.; Brown, J.W.; Schlumpberger, B.O.; Eguiarte, L.E.; Magallon, S. Beyond aridification: Multiple explanations for the elevated diversification of cacti in the New World Succulent Biome. New Phytol. 2014, 202, 1382-1397. [CrossRef] [PubMed]

4. Hernandez-Hernandez, T.; Hernandez, H.M.; De-Nova, J.A.; Puente, R.; Eguiarte, L.E.; Magallon, S. Phylogenetic relationships and evolution of growth form in Cactaceae (Caryophyllales, Eudicotyledoneae). Am. J. Bot. 2011, 98, 44-61. [CrossRef]

5. Majure, L.C.; Baker, M.A.; Cloud-Hughes, M.; Salywon, A.; Neubig, K.M. Phylogenomics in Cactaceae: A case study using the chollas sensu lato (Cylindropuntieae, Opuntioideae) reveals a common pattern out of the Chihuahuan and Sonoran deserts. Am. J. Bot. 2019, 106, 1327-1345. [CrossRef]

6. Walker, J.F.; Yang, Y.; Feng, T.; Timoneda, A.; Mikenas, J.; Hutchison, V.; Edwards, C.; Wang, N.; Ahluwalia, S.; Olivieri, J. From cacti to carnivores: Improved phylotranscriptomic sampling and hierarchical homology inference provide further insight into the evolution of Caryophyllales. Am. J. Bot. 2018, 105, 446-462. [CrossRef]

7. Nobel, P.S. Cacti: Biology and Uses; Univ. of California Press: Berkeley, CA, USA, 2002.

8. Greenfield, A.B. A Perfect Red: Empire, Espionage, and the Quest for the Color. of Desire; Harper Collins: New York, NY, USA, 2009; p. 352.

9. Rosenzopf, E. Sind Eiweißspindeln Virus-Einschlußkörper. Python 1951, 3, 95-101.

10. Milbrath, G.M. Isolation and Characterization of a Virus from Saguaro Cactus. Phytopathology 1972, 62, 739-742. [CrossRef]

11. Weng, Z.; Xiong, Z. Genome organization and gene expression of saguaro cactus carmovirus. J. Gen. Virol. 1997, 78, 525-534. [CrossRef] 
12. Peng, L.; Grinstead, S.; Kinard, G.; Wu, L.P.; Li, R. Molecular characterization and detection of two carlaviruses infecting cactus. Arch. Virol. 2019, 164, 1873-1876. [CrossRef]

13. Blockley, A.L.; Mumford, R.A. Identification and isolation of Impatiens necrotic spot virus from prickly pear cactus (Opuntia microdasys). NEW DISEASE REPORT. Plant Pathol. 2001, 50, 805. [CrossRef]

14. Koenig, R.; Pleij, C.W.; Loss, S.; Burgermeister, W.; Aust, H.; Schiemann, J. Molecular characterisation of potexviruses isolated from three different genera in the family Cactaceae. Arch. Virol. 2004, 149, 903-914. [CrossRef] [PubMed]

15. Min, B.E.; Song, Y.S.; Ryu, K.H. Complete sequence and genome structure of cactus mild mottle virus. Arch. Virol. 2009, 154, 1371-1374. [CrossRef] [PubMed]

16. Min, B.E.; Chung, B.N.; Kim, M.J.; Ha, J.H.; Lee, B.Y.; Ryu, K.H. Cactus mild mottle virus is a new cactus-infecting tobamovirus. Arch. Virol. 2006, 151, 13-21. [CrossRef]

17. Liou, M.R.; Chen, Y.R.; Liou, R.F. Complete nucleotide sequence and genome organization of a Cactus virus X strain from Hylocereus undatus (Cactaceae). Arch. Virol. 2004, 149, 1037-1043. [CrossRef]

18. Sanches, M.M.; Lamas, N.S.; Reis, M.B.; Arieta-Sosa, J.G.; Romano, E.; Melo, F.L.; Ribeiro, S.G. Genome Assembly of Schlumbergera Virus X Infecting Prickly Pear (Opuntia cochenillifera) in Brazil. Genome Announc. 2015, 3, e00133-15. [CrossRef]

19. Villamor, D.E.V.; Ho, T.; Al Rwahnih, M.; Martin, R.R.; Tzanetakis, I.E. High Throughput Sequencing for Plant Virus Detection and Discovery. Phytopathology 2019, 109, 716-725. [CrossRef]

20. Roossinck, M.J.; Martin, D.P.; Roumagnac, P. Plant Virus Metagenomics: Advances in Virus Discovery. Phytopathology 2015, 105, 716-727. [CrossRef]

21. Zerbini, F.M.; Briddon, R.W.; Idris, A.; Martin, D.P.; Moriones, E.; Navas-Castillo, J.; Rivera-Bustamante, R.; Roumagnac, P.; Varsani, A.; Ictv Report, C. ICTV Virus Taxonomy Profile: Geminiviridae. J. Gen. Virol. 2017, 98, 131-133. [CrossRef]

22. Varsani, A.; Roumagnac, P.; Fuchs, M.; Navas-Castillo, J.; Moriones, E.; Idris, A.; Briddon, R.W.; Rivera-Bustamante, R.; Murilo Zerbini, F.; Martin, D.P. Capulavirus and Grablovirus: Two new genera in the family Geminiviridae. Arch. Virol. 2017, 162, 1819-1831. [CrossRef]

23. Loconsole, G.; Saldarelli, P.; Doddapaneni, H.; Savino, V.; Martelli, G.P.; Saponari, M. Identification of a single-stranded DNA virus associated with citrus chlorotic dwarf disease, a new member in the family Geminiviridae. Virology 2012, 432, 162-172. [CrossRef]

24. Ma, Y.; Navarro, B.; Zhang, Z.; Lu, M.; Zhou, X.; Chi, S.; Di Serio, F.; Li, S. Identification and molecular characterization of a novel monopartite geminivirus associated with mulberry mosaic dwarf disease. J. Gen. Virol. 2015, 96, 2421-2434. [CrossRef] [PubMed]

25. Liang, P.; Navarro, B.; Zhang, Z.; Wang, H.; Lu, M.; Xiao, H.; Wu, Q.; Zhou, X.; Di Serio, F.; Li, S. Identification and characterization of a novel geminivirus with a monopartite genome infecting apple trees. J. Gen. Virol. 2015, 96, 2411-2420. [CrossRef]

26. Zhang, S.; Shen, P.; Li, M.; Tian, X.; Zhou, C.; Cao, M. Discovery of a novel geminivirus associated with camellia chlorotic dwarf disease. Arch. Virol. 2018, 163, 1709-1712. [CrossRef]

27. Al Rwahnih, M.; Alabi, O.J.; Westrick, N.M.; Golino, D.; Rowhani, A. Description of a Novel Monopartite Geminivirus and Its Defective Subviral Genome in Grapevine. Phytopathology 2017, 107, 240-251. [CrossRef]

28. Vaghi Medina, C.G.; Teppa, E.; Bornancini, V.A.; Flores, C.R.; Marino-Buslje, C.; Lopez Lambertini, P.M. Tomato Apical Leaf Curl Virus: A Novel, Monopartite Geminivirus Detected in Tomatoes in Argentina. Front. Microbiol. 2017, 8, 2665. [CrossRef]

29. Claverie, S.; Bernardo, P.; Kraberger, S.; Hartnady, P.; Lefeuvre, P.; Lett, J.M.; Galzi, S.; Filloux, D.; Harkins, G.W.; Varsani, A.; et al. From Spatial Metagenomics to Molecular Characterization of Plant Viruses: A Geminivirus Case Study. Adv. Virus Res. 2018, 101, 55-83. [CrossRef]

30. Fontenele, R.S.; Abreu, R.A.; Lamas, N.S.; Alves-Freitas, D.M.T.; Vidal, A.H.; Poppiel, R.R.; Melo, F.L.; Lacorte, C.; Martin, D.P.; Campos, M.A.; et al. Passion Fruit Chlorotic Mottle Virus: Molecular Characterization of a New Divergent Geminivirus in Brazil. Viruses 2018, 10, 169. [CrossRef]

31. Fontenele, R.S.; Lamas, N.S.; Lacorte, C.; Lacerda, A.L.M.; Varsani, A.; Ribeiro, S.G. A novel geminivirus identified in tomato and cleome plants sampled in Brazil. Virus Res. 2017, 240, 175-179. [CrossRef]

32. Zhang, R.; Wu, X.; Jiang, X.; Wu, X.; Luan, X.; Cheng, X. Molecular characterization of common bean curly stunt virus: A novel recombinant geminivirus in China. Arch. Virol. 2020, 165, 257-260. [CrossRef] 
33. Rojas, M.R.; Macedo, M.A.; Maliano, M.R.; Soto-Aguilar, M.; Souza, J.O.; Briddon, R.W.; Kenyon, L.; Rivera Bustamante, R.F.; Zerbini, F.M.; Adkins, S.; et al. World Management of Geminiviruses. Annu. Rev. Phytopathol. 2018, 56, 637-677. [CrossRef]

34. Moffat, A.S. PLANT PATHOLOGY:Geminiviruses Emerge as Serious Crop Threat. Science 1999, $286,1835$. [CrossRef]

35. Bernardo, P.; Golden, M.; Akram, M.; Naimuddin; Nadarajan, N.; Fernandez, E.; Granier, M.; Rebelo, A.G.; Peterschmitt, M.; Martin, D.P.; et al. Identification and characterisation of a highly divergent geminivirus: Evolutionary and taxonomic implications. Virus Res. 2013, 177, 35-45. [CrossRef] [PubMed]

36. Susi, H.; Laine, A.L.; Filloux, D.; Kraberger, S.; Farkas, K.; Bernardo, P.; Frilander, M.J.; Martin, D.P.; Varsani, A.; Roumagnac, P. Genome sequences of a capulavirus infecting Plantago lanceolata in the Aland archipelago of Finland. Arch. Virol. 2017, 162, 2041-2045. [CrossRef] [PubMed]

37. Kraberger, S.; Geering, A.D.W.; Walters, M.; Martin, D.P.; Varsani, A. Novel mastreviruses identified in Australian wild rice. Virus Res. 2017, 238, 193-197. [CrossRef]

38. Zhang, W.; Olson, N.H.; Baker, T.S.; Faulkner, L.; Agbandje-McKenna, M.; Boulton, M.I.; Davies, J.W.; McKenna, R. Structure of the Maize streak virus geminate particle. Virology 2001, 279, 471-477. [CrossRef]

39. Lazarowitz, S.G. Geminiviruses: Genome Structure and Gene Function. Crit. Rev. Plant Sci. 1992, 11, 327. [CrossRef]

40. Fondong, V.N. Geminivirus protein structure and function. Mol. Plant Pathol. 2013, 14, 635-649. [CrossRef]

41. Jeske, H. Geminiviruses. Curr. Top. Microbiol. Immunol. 2009, 331, 185-226. [CrossRef]

42. Roumagnac, P.; Granier, M.; Bernardo, P.; Deshoux, M.; Ferdinand, R.; Galzi, S.; Fernandez, E.; Julian, C.; Abt, I.; Filloux, D.; et al. Alfalfa Leaf Curl Virus: An Aphid-Transmitted Geminivirus. J. Virol. 2015, 89, 9683-9688. [CrossRef]

43. Heydarnejad, J.; Keyvani, N.; Razavinejad, S.; Massumi, H.; Varsani, A. Fulfilling Koch's postulates for beet curly top Iran virus and proposal for consideration of new genus in the family Geminiviridae. Arch. Virol. 2013, 158, 435-443. [CrossRef]

44. Razavinejad, S.; Heydarnejad, J. Transmission and natural hosts of Turnip curly top virus. Iran. J. Plant Pathol. 2013, 49, 27-28.

45. Muhire, B.; Martin, D.P.; Brown, J.K.; Navas-Castillo, J.; Moriones, E.; Zerbini, F.M.; Rivera-Bustamante, R.; Malathi, V.G.; Briddon, R.W.; Varsani, A. A genome-wide pairwise-identity-based proposal for the classification of viruses in the genus Mastrevirus (family Geminiviridae). Arch. Virol. 2013, 158, 1411-1424. [CrossRef] [PubMed]

46. Rocha, C.S.; Castillo-Urquiza, G.P.; Lima, A.T.; Silva, F.N.; Xavier, C.A.; Hora-Junior, B.T.; Beserra-Junior, J.E.; Malta, A.W.; Martin, D.P.; Varsani, A.; et al. Brazilian begomovirus populations are highly recombinant, rapidly evolving, and segregated based on geographical location. J. Virol. 2013, 87, 5784-5799. [CrossRef] [PubMed]

47. Bernardo, P.; Charles-Dominique, T.; Barakat, M.; Ortet, P.; Fernandez, E.; Filloux, D.; Hartnady, P.; Rebelo, T.A.; Cousins, S.R.; Mesleard, F.; et al. Geometagenomics illuminates the impact of agriculture on the distribution and prevalence of plant viruses at the ecosystem scale. ISME J. 2018, 12, 173-184. [CrossRef] [PubMed]

48. Varsani, A.; Shepherd, D.N.; Dent, K.; Monjane, A.L.; Rybicki, E.P.; Martin, D.P. A highly divergent South African geminivirus species illuminates the ancient evolutionary history of this family. Virol. J. 2009, 6, 36. [CrossRef] [PubMed]

49. Rodriguez-Negrete, E.A.; Morales-Aguilar, J.J.; Dominguez-Duran, G.; Torres-Devora, G.; Camacho-Beltran, E.; Leyva-Lopez, N.E.; Voloudakis, A.E.; Bejarano, E.R.; Mendez-Lozano, J. High-Throughput Sequencing Reveals Differential Begomovirus Species Diversity in Non-Cultivated Plants in Northern-Pacific Mexico. Viruses 2019, 11, 594. [CrossRef] [PubMed]

50. Jones, R.A.; Coutts, B.A. Spread of introduced viruses to new plants in natural ecosystems and the threat this poses to plant biodiversity. Mol. Plant Pathol. 2015, 16, 541-545. [CrossRef]

51. Alexander, H.M.; Mauck, K.E.; Whitfield, A.E.; Garrett, K.A.; Malmstrom, C.M. Plant-virus interactions and the agro-ecological interface. Eur. J. Plant Pathol. 2013, 138, 529-547. [CrossRef]

52. Jones, R.A. Plant virus emergence and evolution: Origins, new encounter scenarios, factors driving emergence, effects of changing world conditions, and prospects for control. Virus Res. 2009, 141, 113-130. [CrossRef]

53. Elena, S.F.; Fraile, A.; Garcia-Arenal, F. Evolution and emergence of plant viruses. Adv. Virus Res. 2014, 88, 161-191. [CrossRef] 
54. Cooper, I.; Jones, R.A. Wild plants and viruses: Under-investigated ecosystems. Adv. Virus Res. 2006, 67, 1-47. [CrossRef] [PubMed]

55. Shepherd, D.N.; Martin, D.P.; Lefeuvre, P.; Monjane, A.L.; Owor, B.E.; Rybicki, E.P.; Varsani, A. A protocol for the rapid isolation of full geminivirus genomes from dried plant tissue. J. Virol. Methods 2008, 149, 97-102. [CrossRef]

56. Bankevich, A.; Nurk, S.; Antipov, D.; Gurevich, A.A.; Dvorkin, M.; Kulikov, A.S.; Lesin, V.M.; Nikolenko, S.I.; Pham, S.; Prjibelski, A.D.; et al. SPAdes: A new genome assembly algorithm and its applications to single-cell sequencing. J. Comput. Biol. 2012, 19, 455-477. [CrossRef]

57. Altschul, S.F.; Gish, W.; Miller, W.; Myers, E.W.; Lipman, D.J. Basic local alignment search tool. J. Mol. Biol. 1990, 215, 403-410. [CrossRef]

58. O'Leary, N.A.; Wright, M.W.; Brister, J.R.; Ciufo, S.; Haddad, D.; McVeigh, R.; Rajput, B.; Robbertse, B.; Smith-White, B.; Ako-Adjei, D.; et al. Reference sequence (RefSeq) database at NCBI: Current status, taxonomic expansion, and functional annotation. Nucleic Acids Res. 2016, 44, D733-D745. [CrossRef] [PubMed]

59. Kearse, M.; Moir, R.; Wilson, A.; Stones-Havas, S.; Cheung, M.; Sturrock, S.; Buxton, S.; Cooper, A.; Markowitz, S.; Duran, C.; et al. Geneious Basic: An integrated and extendable desktop software platform for the organization and analysis of sequence data. Bioinformatics 2012, 28, 1647-1649. [CrossRef]

60. Becker, D.; Kemper, E.; Schell, J.; Masterson, R. New plant binary vectors with selectable markers located proximal to the left T-DNA border. Plant Mol. Biol. 1992, 20, 1195-1197. [CrossRef]

61. Muhire, B.M.; Varsani, A.; Martin, D.P. SDT: A virus classification tool based on pairwise sequence alignment and identity calculation. PLoS ONE 2014, 9, e108277. [CrossRef]

62. Katoh, K.; Standley, D.M. MAFFT multiple sequence alignment software version 7: Improvements in performance and usability. Mol. Biol. Evol. 2013, 30, 772-780. [CrossRef]

63. Stover, B.C.; Muller, K.F. TreeGraph 2: Combining and visualizing evidence from different phylogenetic analyses. BMC Bioinform. 2010, 11, 7. [CrossRef]

64. Guindon, S.; Dufayard, J.F.; Lefort, V.; Anisimova, M.; Hordijk, W.; Gascuel, O. New algorithms and methods to estimate maximum-likelihood phylogenies: Assessing the performance of PhyML 3.0. Syst. Biol. 2010, 59, 307-321. [CrossRef] [PubMed]

65. Darriba, D.; Taboada, G.L.; Doallo, R.; Posada, D. jModelTest 2: More models, new heuristics and parallel computing. Nat. Methods 2012, 9, 772. [CrossRef] [PubMed]

66. Darriba, D.; Taboada, G.L.; Doallo, R.; Posada, D. ProtTest 3: Fast selection of best-fit models of protein evolution. Bioinformatics 2011, 27, 1164-1165. [CrossRef]

67. Huang, Y.; Niu, B.; Gao, Y.; Fu, L.; Li, W. CD-HIT Suite: A web server for clustering and comparing biological sequences. Bioinformatics 2010, 26, 680-682. [CrossRef]

68. Gerlt, J.A.; Bouvier, J.T.; Davidson, D.B.; Imker, H.J.; Sadkhin, B.; Slater, D.R.; Whalen, K.L. Enzyme Function Initiative-Enzyme Similarity Tool (EFI-EST): A web tool for generating protein sequence similarity networks. Biochim. Biophys. Acta 2015, 1854, 1019-1037. [CrossRef]

69. Shannon, P.; Markiel, A.; Ozier, O.; Baliga, N.S.; Wang, J.T.; Ramage, D.; Amin, N.; Schwikowski, B.; Ideker, T. Cytoscape: A software environment for integrated models of biomolecular interaction networks. Genome Res. 2003, 13, 2498-2504. [CrossRef]

70. Martin, D.P.; Murrell, B.; Golden, M.; Khoosal, A.; Muhire, B. RDP4: Detection and analysis of recombination patterns in virus genomes. Virus Evol. 2015, 1, vev003. [CrossRef]

71. Martin, D.; Rybicki, E. RDP: Detection of recombination amongst aligned sequences. Bioinformatics 2000, 16, 562-563. [CrossRef]

72. Padidam, M.; Sawyer, S.; Fauquet, C.M. Possible emergence of new geminiviruses by frequent recombination. Virology 1999, 265, 218-225. [CrossRef]

73. Martin, D.P.; Posada, D.; Crandall, K.A.; Williamson, C. A modified bootscan algorithm for automated identification of recombinant sequences and recombination breakpoints. AIDS Res. Hum. Retrovir. 2005, 21, 98-102. [CrossRef]

74. Smith, J.M. Analyzing the mosaic structure of genes. J. Mol. Evol. 1992, 34, 126-129. [CrossRef] [PubMed]

75. Posada, D.; Crandall, K.A. Evaluation of methods for detecting recombination from DNA sequences: Computer simulations. Proc. Natl. Acad. Sci. USA 2001, 98, 13757-13762. [CrossRef] [PubMed] 
76. Gibbs, M.J.; Armstrong, J.S.; Gibbs, A.J. Sister-scanning: A Monte Carlo procedure for assessing signals in recombinant sequences. Bioinformatics 2000, 16, 573-582. [CrossRef] [PubMed]

77. Boni, M.F.; Posada, D.; Feldman, M.W. An exact nonparametric method for inferring mosaic structure in sequence triplets. Genetics 2007, 176, 1035-1047. [CrossRef] [PubMed]

78. Argüello-Astorga, G.; Guevara-Gonzalez, R.; Herrera-Estrella, L.; Rivera-Bustamante, R. Geminivirus replication origins have a group-specific organization of iterative elements: A model for replication. Virology 1994, 203, 90-100. [CrossRef] [PubMed]

79. Varsani, A.; Krupovic, M. Sequence-based taxonomic framework for the classification of uncultured single-stranded DNA viruses of the family Genomoviridae. Virus Evol. 2017, 3, vew037. [CrossRef]

80. Nash, T.E.; Dallas, M.B.; Reyes, M.I.; Buhrman, G.K.; Ascencio-Ibanez, J.T.; Hanley-Bowdoin, L. Functional analysis of a novel motif conserved across geminivirus Rep proteins. J. Virol. 2011, 85, 1182-1192. [CrossRef]

81. Lefeuvre, P.; Martin, D.P.; Elena, S.F.; Shepherd, D.N.; Roumagnac, P.; Varsani, A. Evolution and ecology of plant viruses. Nat. Rev. Microbiol. 2019, 17, 632-644. [CrossRef]

82. Monjane, A.L.; Harkins, G.W.; Martin, D.P.; Lemey, P.; Lefeuvre, P.; Shepherd, D.N.; Oluwafemi, S.; Simuyandi, M.; Zinga, I.; Komba, E.K.; et al. Reconstructing the history of maize streak virus strain a dispersal to reveal diversification hot spots and its origin in southern Africa. J. Virol. 2011, 85, 9623-9636. [CrossRef]

83. Lefeuvre, P.; Martin, D.P.; Harkins, G.; Lemey, P.; Gray, A.J.; Meredith, S.; Lakay, F.; Monjane, A.; Lett, J.M.; Varsani, A.; et al. The spread of tomato yellow leaf curl virus from the Middle East to the world. PLoS Pathog. 2010, 6, e1001164. [CrossRef]

84. De Bruyn, A.; Harimalala, M.; Zinga, I.; Mabvakure, B.M.; Hoareau, M.; Ravigne, V.; Walters, M.; Reynaud, B.; Varsani, A.; Harkins, G.W.; et al. Divergent evolutionary and epidemiological dynamics of cassava mosaic geminiviruses in Madagascar. BMC Evol. Biol. 2016, 16, 182. [CrossRef] [PubMed]

85. Harkins, G.W.; Martin, D.P.; Duffy, S.; Monjane, A.L.; Shepherd, D.N.; Windram, O.P.; Owor, B.E.; Donaldson, L.; van Antwerpen, T.; Sayed, R.A.; et al. Dating the origins of the maize-adapted strain of maize streak virus, MSV-A. J. Gen. Virol. 2009, 90, 3066-3074. [CrossRef] [PubMed]

86. De Bruyn, A.; Villemot, J.; Lefeuvre, P.; Villar, E.; Hoareau, M.; Harimalala, M.; Abdoul-Karime, A.L.; Abdou-Chakour, C.; Reynaud, B.; Harkins, G.W.; et al. East African cassava mosaic-like viruses from Africa to Indian ocean islands: Molecular diversity, evolutionary history and geographical dissemination of a bipartite begomovirus. BMC Evol. Biol. 2012, 12, 228. [CrossRef] [PubMed]

87. Mabvakure, B.; Martin, D.P.; Kraberger, S.; Cloete, L.; van Brunschot, S.; Geering, A.D.W.; Thomas, J.E.; Bananej, K.; Lett, J.M.; Lefeuvre, P.; et al. Ongoing geographical spread of Tomato yellow leaf curl virus. Virology 2016, 498, 257-264. [CrossRef]

88. Rybicki, E.P. A phylogenetic and evolutionary justification for three genera of Geminiviridae. Arch. Virol. 1994, 139, 49-77. [CrossRef]

89. Stanley, J.; Markham, P.G.; Callis, R.J.; Pinner, M.S. The nucleotide sequence of an infectious clone of the geminivirus beet curly top virus. EMBO J. 1986, 5, 1761-1767. [CrossRef]

90. Briddon, R.W.; Bedford, I.D.; Tsai, J.H.; Markham, P.G. Analysis of the nucleotide sequence of the treehopper-transmitted geminivirus, tomato pseudo-curly top virus, suggests a recombinant origin. Virology 1996, 219, 387-394. [CrossRef]

91. Bernardo, P.; Muhire, B.; Francois, S.; Deshoux, M.; Hartnady, P.; Farkas, K.; Kraberger, S.; Filloux, D.; Fernandez, E.; Galzi, S.; et al. Molecular characterization and prevalence of two capulaviruses: Alfalfa leaf curl virus from France and Euphorbia caput-medusae latent virus from South Africa. Virology 2016, 493, 142-153. [CrossRef]

92. Kraberger, S.; Thomas, J.E.; Geering, A.D.; Dayaram, A.; Stainton, D.; Hadfield, J.; Walters, M.; Parmenter, K.S.; van Brunschot, S.; Collings, D.A.; et al. Australian monocot-infecting mastrevirus diversity rivals that in Africa. Virus Res. 2012, 169, 127-136. [CrossRef]

93. Kamali, M.; Heydarnejad, J.; Massumi, H.; Kvarnheden, A.; Kraberger, S.; Varsani, A. Molecular diversity of turncurtoviruses in Iran. Arch. Virol. 2016, 161, 551-561. [CrossRef] [PubMed]

94. Varsani, A.; Martin, D.P.; Navas-Castillo, J.; Moriones, E.; Hernandez-Zepeda, C.; Idris, A.; Murilo Zerbini, F.; Brown, J.K. Revisiting the classification of curtoviruses based on genome-wide pairwise identity. Arch. Virol. 2014, 159, 1873-1882. [CrossRef] [PubMed] 
95. Varsani, A.; Shepherd, D.N.; Monjane, A.L.; Owor, B.E.; Erdmann, J.B.; Rybicki, E.P.; Peterschmitt, M.; Briddon, R.W.; Markham, P.G.; Oluwafemi, S.; et al. Recombination, decreased host specificity and increased mobility may have driven the emergence of maize streak virus as an agricultural pathogen. J. Gen. Virol. 2008, 89, 2063-2074. [CrossRef] [PubMed]

96. Lefeuvre, P.; Martin, D.P.; Hoareau, M.; Naze, F.; Delatte, H.; Thierry, M.; Varsani, A.; Becker, N.; Reynaud, B.; Lett, J.M. Begomovirus 'melting pot' in the south-west Indian Ocean islands: Molecular diversity and evolution through recombination. J. Gen. Virol. 2007, 88, 3458-3468. [CrossRef] [PubMed]

97. Lefeuvre, P.; Lett, J.M.; Varsani, A.; Martin, D.P. Widely conserved recombination patterns among single-stranded DNA viruses. J. Virol. 2009, 83, 2697-2707. [CrossRef]

98. Garcia-Andres, S.; Tomas, D.M.; Sanchez-Campos, S.; Navas-Castillo, J.; Moriones, E. Frequent occurrence of recombinants in mixed infections of tomato yellow leaf curl disease-associated begomoviruses. Virology 2007, 365, 210-219. [CrossRef]

99. Stanley, J.; Townsend, R.; Curson, S.J. Pseudorecombinants between Cloned DNAs of Two Isolates of Cassava Latent Virus. J. Gen. Virol. 1985, 66, 1055-1061. [CrossRef]

100. Casado, C.G.; Javier Ortiz, G.; Padron, E.; Bean, S.J.; McKenna, R.; Agbandje-McKenna, M.; Boulton, M.I. Isolation and characterization of subgenomic DNAs encapsidated in "single" T $=1$ isometric particles of Maize streak virus. Virology 2004, 323, 164-171. [CrossRef]

101. Macdonald, H.; Coutts, R.H.A.; Buck, K.W. Characterization of a Subgenomic DNA Isolated from Triticum Aestivum Plants Infected with Wheat Dwarf Virus. J. Gen. Virol. 1988, 69, 1339-1344. [CrossRef]

102. Behjatnia, S.A.; Dry, I.B.; Rezaian, M.A. Characterization and transient replication of tomato leaf curl virus defective DNAs. Arch. Virol. 2007, 152, 1127-1138. [CrossRef]

103. Liu, Y.; Robinson, D.J.; Harrison, B.D. Defective forms of cotton leaf curl virus DNA-A that have different combinations of sequence deletion, duplication, inversion and rearrangement. J. Gen. Virol. 1998, 79 (Pt. 6), 1501-1508. [CrossRef]

104. Horn, J.; Lauster, S.; Krenz, B.; Kraus, J.; Frischmuth, T.; Jeske, H. Ambivalent effects of defective DNA in beet curly top virus-infected transgenic sugarbeet plants. Virus Res. 2011, 158, 169-178. [CrossRef] [PubMed]

105. Van der Walt, E.; Rybicki, E.P.; Varsani, A.; Polston, J.E.; Billharz, R.; Donaldson, L.; Monjane, A.L.; Martin, D.P. Rapid host adaptation by extensive recombination. J. Gen. Virol. 2009, 90, 734-746. [CrossRef] [PubMed]

106. Hadfield, J.; Thomas, J.E.; Schwinghamer, M.W.; Kraberger, S.; Stainton, D.; Dayaram, A.; Parry, J.N.; Pande, D.; Martin, D.P.; Varsani, A. Molecular characterisation of dicot-infecting mastreviruses from Australia. Virus Res. 2012, 166, 13-22. [CrossRef] [PubMed]

107. Patil, B.L.; Dasgupta, I. Defective Interfering DNAs of Plant Viruses. Crit. Rev. Plant Sci. 2006, 25, 47-64. [CrossRef]

108. Patil, B.L.; Dutt, N.; Briddon, R.W.; Bull, S.E.; Rothenstein, D.; Borah, B.K.; Dasgupta, I.; Stanley, J.; Jeske, H. Deletion and recombination events between the DNA-A and DNA-B components of Indian cassava-infecting geminiviruses generate defective molecules in Nicotiana benthamiana. Virus Res. 2007, 124, 59-67. [CrossRef] [PubMed]

109. Bach, J.; Jeske, H. Defective DNAs of beet curly top virus from long-term survivor sugar beet plants. Virus Res. 2014, 183, 89-94. [CrossRef] [PubMed]

110. Catoni, M.; Noris, E.; Vaira, A.M.; Jonesman, T.; Matic, S.; Soleimani, R.; Behjatnia, S.A.A.; Vinals, N.; Paszkowski, J.; Accotto, G.P. Virus-mediated export of chromosomal DNA in plants. Nat. Commun. 2018, 9, 5308. [CrossRef]

111. Martin, D.P.; Biagini, P.; Lefeuvre, P.; Golden, M.; Roumagnac, P.; Varsani, A. Recombination in eukaryotic single stranded DNA viruses. Viruses 2011, 3, 1699-1738. [CrossRef]

112. Frischmuth, T.; Ringel, M.; Kocher, C. The size of encapsidated single-stranded DNA determines the multiplicity of African cassava mosaic virus particles. J. Gen. Virol. 2001, 82, 673-676. [CrossRef]

(C) 2020 by the authors. Licensee MDPI, Basel, Switzerland. This article is an open access article distributed under the terms and conditions of the Creative Commons Attribution (CC BY) license (http://creativecommons.org/licenses/by/4.0/). 